\title{
The genus Oxyethira Eaton (Trichoptera, Hydroptilidae) in Japan
}

\author{
T. ITO ${ }^{1 *}$ and J. OLÁH ${ }^{2}$ \\ ${ }^{1}$ Tomiko Ito, Hokkaido Aquatic Biology, Hakuyo-cho, 3-3-5, Eniwa, Hokkaido 061-1434, Japan. \\ ${ }^{2} J a ́ n o s$ Oláh, Tarján u. 28, H-4032 Debrecen, Hungary.E-mail: profolah@gmail.com \\ *Correspoding author e-mail: tobikera@siren.ocn.ne.jp
}

\begin{abstract}
The Japanese species of Oxyethira Eaton (Trichoptera, Hydroptilidae) are reviewed confirming 8 described species, and introducing 2 new species, $O$. tsuruga and $O$. shumari spp. nov. For clear comparisons and to include new details, males of all the 10 species and females of 9 species, except $O$. ozea Oláh and Ito, 2013 are redescribed or described. O. kakida Oláh and Ito, 2013 is synonymized with O. angustella Martynov, 1933.
\end{abstract}

Keywords. Micro-caddisfly, Oxyethira, new species, new synonymy, variation, Japan.

\section{INTRODUCTION}

$\mathrm{T}$ he micro-caddisfly genus Oxyethira Eaton, 1873 is widely distributed in the world (Marshall 1979). For Japan, 9 named species belonging subgenus Oxyethira Easton, 1873 were recorded (Martynov 1933, Oláh \& Ito 2013). However, 2 taxonomic problems remained: (1) the taxonomic status of $O$. angustella Martynov, 1933, described from Sinano, Honshu, Japan, is unclear due to the insufficient description; (2) unidentified adults have been collected in Japan (Ohtaka et al. 2008, Shimura et al. 2014, Ito 2017).

As a consequence of this study on recently collected specimens of Japanese Oxyethira, 10 species are now recognized in the Japanese fauna. Adults of all named species are redescribed to enable clear, unambiguous comparisons, and 2 new species are described. One name is newly synonymized and the true nature of $O$. angustella is resolved.

\section{MATERIALS AND METHODS}

Association of male and female was based on similar general characteristics, such as color and size, within specimens collected together. Male and female genitalia were figured after treatment in about $5 \% \mathrm{KOH}$. In order to show genital segments in detail, segments VIII of males are drawn with thicker lines and sometimes shown in separate figures. Morphological terms mainly follow Oláh and Ito (2013) for males and Kelley (1984) for females. The type series of the new species are deposited in the collections of the Natural History Museum and Institute, Chiba (CBM-ZI). Other specimens are deposited in the collection of the senior author (T. Ito) and all specimens are preserved in $80 \%$ ethyl alcohol, unless otherwise indicated in parentheses. The collecting methods and collectors are abbreviated as follows: light trap (L), sweep net (S), Tomiko Ito (TI).

\section{TAXONOMY}

\section{Oxyethira acuta Kobayashi, 1977}

(Figures 1, 12)

Oxyethira acuta Kobayashi, 1977, 6-7, pls. 5-6, male, female, Hokkaido (Iburi); Ito \& Kawamula, 1984, 313-317, pupa, larva, case, life cycle, Hokkaido (Iburi); Ito, 2005, 442, 444, larva, case; Oláh \& Ito, 2013, 32, figs. 17-20, male, Hokkaido (Kushiro, Ishikari, Iburi).

Oxyethira sp.: Ohtaka et al., 2008, 60, Honshu (Aomori). 
Material examined. Additional records to Oláh \& Ito (2013). Hokkaido: 15 males, 369 females, Kushiro-shi, Akan-panke-ko, 31.viii. 1996-27.vii. 2012, TI et al., L \& S (1 female, 31.viii.1996; 1 male, 6 females, 13.viii.1997; 1 male, 1 female, 10.vii.1998; 2 females, 21.viii.1998; 7 males, 2 females, 14.ix.1998; 1 male, 1.x.2010; 5 males, 357 females, 27.vii.2012); 4 females, Kushiro-shi, Akan-kohan, Ibeshibetsu, 23.vii.1996-31.viii. 1996, TI et al., L (1 female, 23.vii.1996; 3 females, 31.viii.1996); 5 males, 2 females, Shibecha-cho, Shirarutoro-ko, Ikoino-ie, 29.viii.2005, TI, L; 2 males, 2 females, Shibecha-cho, Shirarutoro-ko, eastern bank, 25.vii.2008, TI, L; 6 males, 1 female, Sarufutsu-mura, Kamuito-numa, 31.vii.2007, TI, L; 119 males, 34 females, Sapporo-shi, Nopporo, Mizuho-ike, 14.vii.2004, Y. Nagayasu \& TI, L; 137 males, 75 females, Tomakomai-shi, Utonai-ko, 17.v.1977-17.viii.207, TI et al., L \& S (2 males, 9 females, 17.v.1977; 6 males, 9 females, 6.viii.1977; 2 males, 3 females, 29.vii. 1998; 5 females, 28.vi.1999; 7 males, 6 females, 22.vii.2001; 108 males, 6 females, 22.vii.2004; 12 males, 37 females, 17.viii.2007); 1 female, Tomakomai-shi, Bibi-gawa, Uenae-bashi, 22.vii.2001, TI, L; 3 males, 97 females, Tomakomai-shi, Bibi- gawa, 4 m a.s.1., 22.vii. 20015.viii.2010, TI, L (3 females, 8.vii.2010; 3 males, 94 females, 5.viii. 2010). Honshu. Aomori: 17 males, 6 females, Goshogawara-shi, Myojin-numa, 23.v-21.ix.2007, T. Ogasawara, L (mounted on slide and deposited in the personal collection of T. Ogasawara) (6 males, 4 females, 23.v.2007; 10 males, 2 females, 18.vi. 2007; 1 male, 21.ix. 2007). Okayama: 14 males, 3 females, Waki-cho, Fujino, Kongo-gawa, 24.vii. 2016, K. Nojima.

Adult. Wings light brown with several small lighter markings. Antennae brown to light brown with darker marking near apices. Spur formula 0 , 3,4 .

Male. Length of forewing and hind wing $2.6-2.8 \mathrm{~mm}$ and $1.9-2.1 \mathrm{~mm}$, respectively $(\mathrm{n}=5)$. Antennae 38-42 segmented; length $2.3-2.5 \mathrm{~mm}$ $(\mathrm{n}=5)$. Apicomesal process of sternite VII (app) short and acute. Segment VIII annular, gently protruded posteriorly in lateral view; both anterior and posterior margins with wide and shallow excision in dorsal view; anterior margin almost straight and posterior margin largely concave in ventral view. Segment IX completely enclosed within segment VIII; dorsum slightly shorter than ventrum in lateral view; subquadrate with undulate anterior margin in dorsal view; subquadrate with almost straight anterior margin in ventral view. Segment $X$ reduced to low membranous lobe. Pair of paraproct (pp) heavily sclerotized, triangular in lateral view, semi-circular basal halves and mesally curved triangle apical halves in dorsal view. Basal plate of gonopods (bpgo) originating at basoventral margin of gonopods. Gonopods (go) small, triangle, fused to sternite IX at base. A pair of short, membranous setal lobes (sl) with a few short setae at mesal surface of gonopods. Phallic organ with paramere (pa) encircling shaft once and split into 2 tape-like arms and 1 longest filiform, elongated posteriorly, filiform shorter than aedeagus (ae) and longer than tape-like arms; arms and filiform somewhat variable individually, one of tape-like arms directed dorsad in some specimens of Lake Akanpanke-ko, Hokkaido, one of tape-like arms distinctly shorter than another arm in a male of Lake Myojin-numa, Aomori.

Female. Length of forewing and hind wing $2.7-3.2 \mathrm{~mm}$ and $2.3 \mathrm{~mm}$, respectively $(\mathrm{n}=5)$. Antennae 25-26 segmented and $1.1-1.3 \mathrm{~mm}$ long $(n=5)$. Sternite VI with small acute apicomesal process. Tergites of VIII and X weakly sclerotized, segment IX membranous dorsally. Sternite VIII with two round sclerites, reddish brown, conspicuous.

Remarks. This species belongs to the ecornuta species cluster Oláh and Ito, 2013, the flavicornis species group Kelley, 1984 (Oláh \& Ito, 2013), and is distinguished from other congeneric Japanese species by shape of gonopods (semicircular basal half and mesally curved apical half) and phallic organ with 2 tape-like arms and longest filiform in male and 2 round sclerites of sternite VIII in female.

Distribution (Fig. 12). Hokkaido (Kushiro, Soya, Ishikari, Iburi), Honshu (Aomori, Okayama). New to Honshu. 


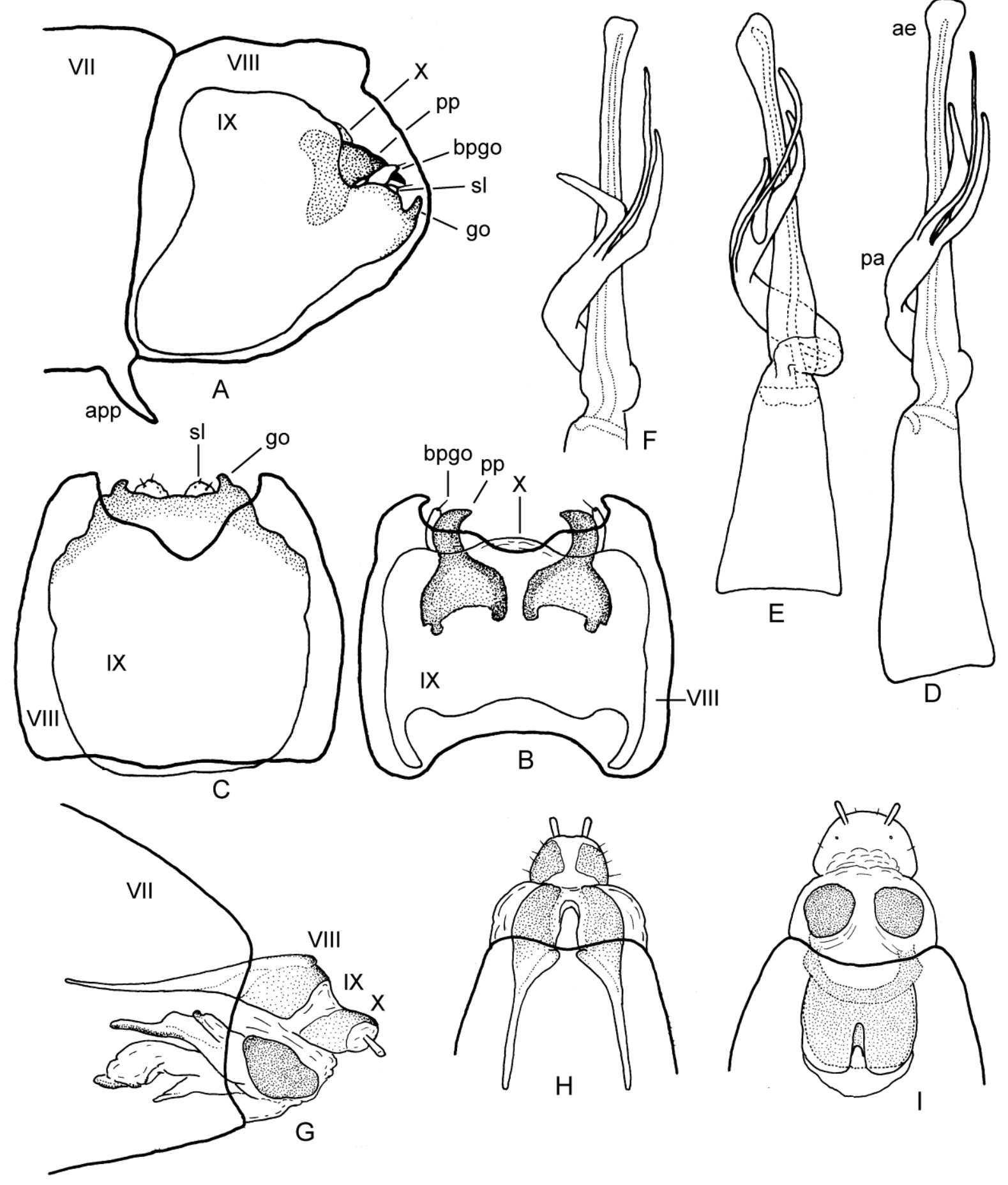

Figure 1. Oxyethira acuta. Male (A-E): A = abdominal segments VII-X, left lateral; $\mathrm{B}=$ genitalia, dorsal; $\mathrm{C}=$ same, ventral; D-F = phallus, left lateral. Female $(\mathrm{G}-\mathrm{I})$ : G = abdominal segments VII-X, lateral; H = same, dorsal; $\mathrm{I}=$ same, ventral. Materials: A-D \& G-I, Lake Utonai-ko, Hokkaido (type locality); E, Lake Myojin-numa, Aomori; F, Lake Akanpanke-ko, Hokkaido. Abbreviations: VII-X = abdominal segments VII-X; ae = aedeagus; app = apicomesal process; bpgo = basal plate of gonopods; go = gonopods; $\mathrm{pa}=$ paremere; $\mathrm{pp}=$ paraproct $; \mathrm{sl}=$ setal lobe . 
Habitat and ecology. Adults of this species were collected from lakes and ponds. The larvae live in assemblages of water plants such as Phragmites sp. (Gramineae) and suck cell contents of filamentous algae associated to leaves and stems of the plants (Ito \& Kawamula 1984). This species has an univoltine life cycle with summer emergent period in the type locality, Lake Utonai-ko, Tomakomai, Hokkaido (Ito \& Kawamula 1984).

Japanese name. Hagoita-himetobikera.

\section{Oxyethira angustella Martynov, 1933}

(Figures 2, 12)

Oxyethira angustella Martynov, 1933, 139, antenna, mouth parts and wings of female, Honshu (Shinano $=$ old name of Nagano).

Oxyethira kakida Oláh \& Ito, 2013, 30-31, figs. 9-12, male, Hokkaido (Nemuro, Kushiro, Tokachi, Ishikari), Honshu (Yamagata, Tokyo, Shizuoka); Nozaki et al., in press, Honshu (Nagano). New synonym.

Material examined. Additional records to Oláh \& Ito (2013). Hokkaido: 17 males, Shibetsu-cho, Ichani-gawa, Chishine-bashi, 12.ix.1995-21.vii. 1996, TI \& A. Ohkawa, L (6 males, 12.ix.1995; 6 males, 28.vi.1996; 5 males, 21.viii.1996); 1 male, Kushiro-shi, Akan-kohan Kinetanpe, 21.ix.1996, TI, L; 1 male, Eniwa-shi, Izari-gawa, Rarumanai-no-taki, 15-21.vii.2001, TI, L; 1 male, Eniwa-shi, Izari-gawa, Eniwa-ohashi, 1.viii.2015, TI, L; 2 males, Chitose-shi, Chitose-ko, 25.viii.2001, TI, L; 67 males, Chitose-shi, Bibi-gawa, Bibibashi, 29.viii.1991-6.ix.2007, TI et al., L (36 males, 29.viii.1991; 3 males, 17.ix.1992; 2 males, 22.v.1998; 3 males, 24.ix.1999; 3 males, 15.vii. 2001; 17 males, 8.ix.2002; 3 males, 6.ix.2007); 2 males, Tomakomai-shi, Bibi-gawa, Matsubibibashi, 21.vii.1990-12.ix.1993, TI, L (1 male, 21. vii.1990; 1 male, 12.ix.1993); 18 males, Tomakomai-shi, Bibi-gawa, Uenae-bashi, 17.vii.197716.vii.2008, TI, L (7 males, 17.vii.1977; 3 males, 22.vii.2001; 6 males, 3.viii.2007; 2 males, 16. vii.2008); 9 males, Tomakomai-shi, Bibi-gawa, 4 m a.s.1., 8.vii.2010-26.vi.2012, TI, L (7 males, 8.vii.2010; 1 male, 5.viii.2010; 1 male, 26.vi. 2012). Honshu. Yamagata: 11 males, Kaneyama- machi, Kanayama-gawa, Arakane-bashi, 11.x. 1999, A. Ohkawa; 2 males, Kaneyama-machi, Kanayama-gawa, Kanayama-bashi, 14.x.1999, A. Ohkawa. Nagano: 136 males, 107 females, a spring, Shimauchi, Matsumoto, 2013-2014 (as $O$. kakida, detail data in Nozaki et al. in press); 1 male, Hakuba-mura, Sano, a headwater of Himekawa, 28.v.1995, T. Hattori; 1 male, Azumino-shi, a spring, 29.v.1999, H. Nishimoto.

Adult. Wings light brown with several small lighter markings. Antennae brown to light brown with darker marking near apices. Spur formula 0 , 3,4 .

Male. Length of forewing and hind wing 2.2$3.0 \mathrm{~mm}$ and $2.5-3.1 \mathrm{~mm}$, respectively $(\mathrm{n}=9)$. Antennae 37-45 segmented $(n=61)$, length $2.1-2.6$ $\mathrm{mm}(\mathrm{n}=7)$. Apicomesal process of sternite VII short and acute. Segment VIII annular, sub quadrate with large excision at each of anterodorsal margin and postero-ventral margin. Segment IX almost completely enclosed within segment VIII; dorsum slightly shorter than ventrum; subquadrate with asymmetrically excised anterior margin in dorsal view; subquadrate with more or less protruded anterior margin in ventral view. Segment $X$ reduced to membranous lobe. Pair of paraproct heavily sclerotized, triangular with truncate apices in lateral view, thin triangular in dorsal view. Long basal plates of gonopods at basoventral margin of gonopods. Gonopods triangle, larger than paraproct in lateral view, fused to sternite IX at base. Setal lobes at mesal surface of gonopods. Phallic organ with paramere encircling shaft once and split into a filiform and a more complex arm; filiform wide at base, gradually tapered with subacute apex; complex arm thick, semi-membranous with blunt apex and an anteriad directed axial spine.

Variation. Antero-dorsal margin of segment IX variable individually; round in holotype male (incorrectly illustrated in Oláh \& Ito 2013), but somewhat convex in paratype males.

Female. Length of forewing and hind wing $2.9-3.3 \mathrm{~mm}$ and $2.5-2.8 \mathrm{~mm}$, respectively $(\mathrm{n}=5)$. Antennae 25-29 segmented, light brown with 4-5 

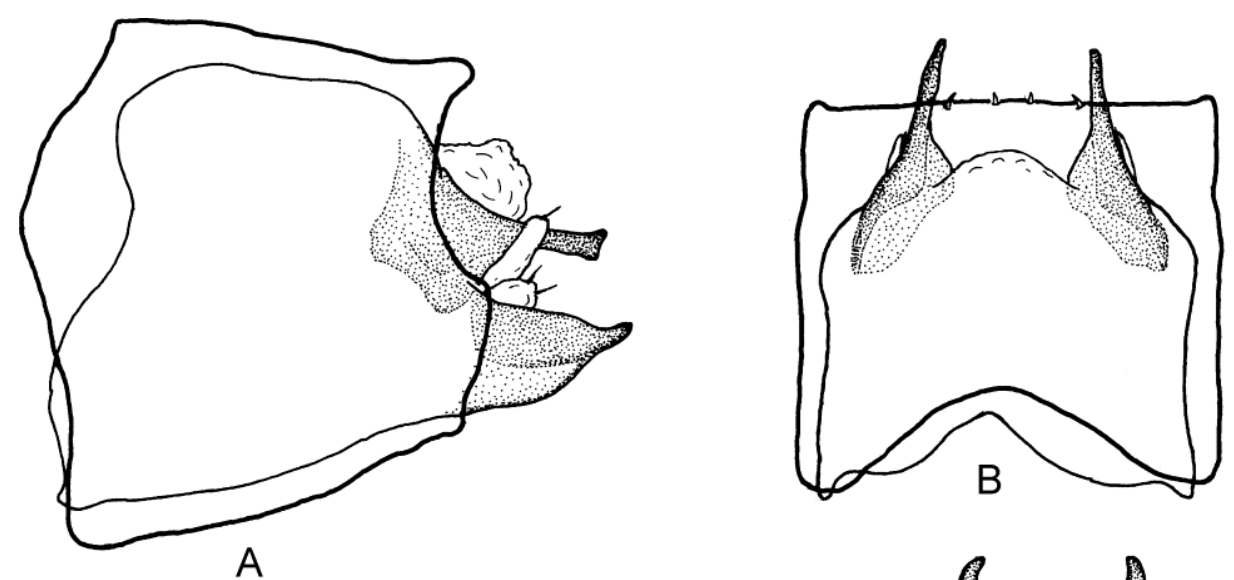

A
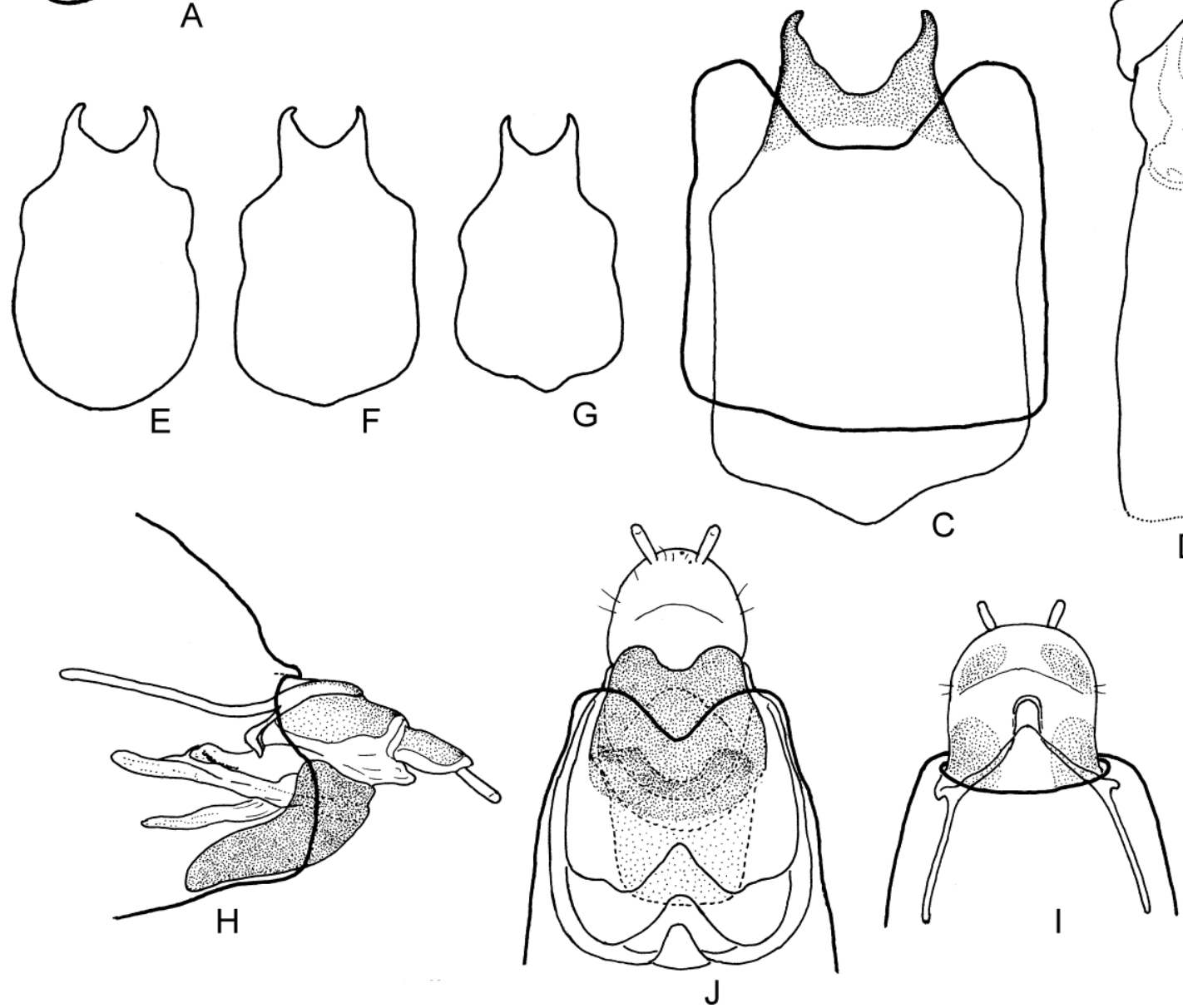

$\mathrm{H}$

Figure 2. Oxyethira angustella. Male (A-G): A = genitalia, left lateral; $\mathrm{B}=$ same, dorsal; $\mathrm{C}=$ same, ventral; $\mathrm{D}=$ phallus, left lateral; E-G = segment IX, ventral. Female $(\mathrm{H}-\mathrm{J})$ : $\mathrm{H}=$ abdominal segments VII-X, lateral; I = same, dorsal; $\mathrm{J}=$ same, ventral.

Materials: A-D \& H-J, Shimauchi-yusui, Matsumoto; E, holotype of O. kakida; F and G, paratypes of $O$. kakida.

dark segments sub-apically $(n=28)$ and $1.1-1.3$ $\mathrm{mm}$ long ( $\mathrm{n}=7)$. Sternite VI with small acute apicomesal process. Tergites of VIII and X weakly sclerotized, IX membranous. Sternite VIII with dark brown, large subquadrate sclerite; in ventral view, anterior margin gently convex, posterior margin with middle round excision.

Remarks. This species was originally described based on a female collected from a 
limnocrene, Matsumoto, Shinano (old name of Nagano Prefecture), Honshu, Japan on December 15, 1931 (Martynov 1933). The type specimen is missing (T. S. Vshivkova personal communication) and the exact site of the type locality is unknown. However, Martynov's description, especially segment number of antenna (29) and venation of hind wing, is coincided with $107 \mathrm{fe}-$ male specimens collected from a spring stream, Shimauchi, Matsumoto, Nagano Prefecture, by a Malaise trap from April 11, 2013 to June 5, 2014 (Nozaki et al. in press). The 136 males collected together with the females are identified to $O$. kakida Oláh \& Ito, 2013 and any other congeneric species didn't occur there. Therefore, we recognized that $O$. kakida Oláh \& Ito, 2013 is a junior synonym of $O$. angustella Martynov, 1933.

This species belongs to the datra species cluster Oláh and Ito, 2013, the flavicornis species group Kelley, 1984 (Oláh \& Ito 2013), and is distinguished from other Japanese species by shape of paramere of phallic organ which has blunt apex and anteriorly directed axial spine of complex arm. O. angustella is similar to a Korean species, O. josifovi Kumanski, 1990 in having anteriorly directed axial spine of complex arm of phallic apparatus. However, $O$. angustella is clearly different from $O$. josifovi as follows: complex arm with 3 very sharp sclerites apically in O. josifovi (Kumanski 1990, Oláh \& Ito 2013), but blunt apically in $O$. angustella.

Females of this species are characterized with strongly sclerotized large sclerite of sternite VIII and 4-5 dark subapical segments of antennae. However, the females of this species are rather similar to O. chitosea Oláh and Ito, 2013 as described below and difficult to discriminate from the later if they were deposited in alcohol more than several months. The female genitalia are described here for the first time.

Distribution (Fig. 12). Hokkaido (Nemuro, Kushiro, Tokachi, Ishikari, Iburi), Honshu (Yamagata, Tokyo, Nagano, Shizuoka). Most common species of this genus in Japan.
Habitat. Adults were widely collected from springs, mountain streams, and marshes.

Japanese name. Kakida-hagoita-himetobikera (newly given here).

\section{Oxyethira chitosea Oláh \& Ito, 2013}

(Figures 3, 12)

Oxyethira chitosea Oláh \& Ito, 2013, 38-39, figs. 39-42, male, Hokkaido (Kushiro, Ishikari); Ito, 2017, 3, Honshu (Fukui).

Material examined. Additional records to Oláh \& Ito (2013). Hokkaido: 1 male, Shibetsu-cho, Ichani-gawa, Chishine-bashi, 28.vi.1996, TI \& A. Ohkawa, L; 1 male, Shibecha-cho, Shirarutoroetoro-gawa, Tomi-bashi, 26.viii.2009, TI, L; 29 males, Kushiro-shi, Akan-panke-ko, 1.vii.19961.x.2010, TI et al., L \& S (12 males, 1.vii.1996; 1 male, 23.vii.1996; 3 males, 31.viii.1996; 5 males, 10.vii.1998; 4 males, 21.viii.1998; 2 males, 14.ix. 1999; 2 males, 1.x.2010); 1 male, Kushiro-shi, Akan-kohan, Churui, 14.ix.1999, TI et al., L; 1 male, Eniwa-shi, Ichankoppe-zawa, $300 \mathrm{~m}$ a.s.l., 10.viii.2010, TI, L; 2 males, Eniwa-shi, Izarigawa, Suisei-bashi, 17.viii.2001, TI, L; 6 males, 11 females, Eniwa-shi, Izari-gawa, Sakae-bashi, vii-viii.2016, TI, L; 2 males, Chitose-shi, Mombetsu-gawa, middle reach, 14.vii.2000, TI et al., L; 9 males, Chitose-shi, Chitose-ko, 8.vii-25. viii.2001, TI \& A. Ohkawa, L. Honshu. Fukui: 5 males, 105 females, Tsuruga-shi, Ikenokochishitsugen, 2013-2016, TI, L (detail data in Ito, 2017).

Adult. Wings light brown with several small lighter markings. Antennae brown to light brown with darker marking near apices. Spur formula 0 , 3,4 .

Male. Length of forewing, hind wing 2.2-2.9 $\mathrm{mm}$ and $1.7-2.2 \mathrm{~mm}$, respectively $(\mathrm{n}=5)$. Antennae 35-42 segmented; length $1.8-2.2 \mathrm{~mm}(\mathrm{n}=5)$. Apicomesal process of sternite VII short and acute. Segment VIII annular, subquadrate with shallow excide at dorso-posterior margin and deep 


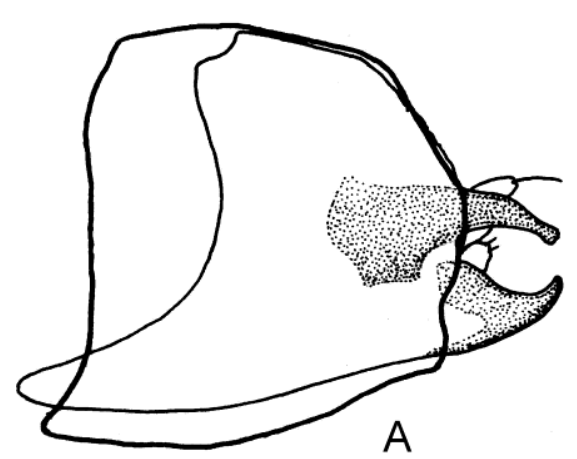

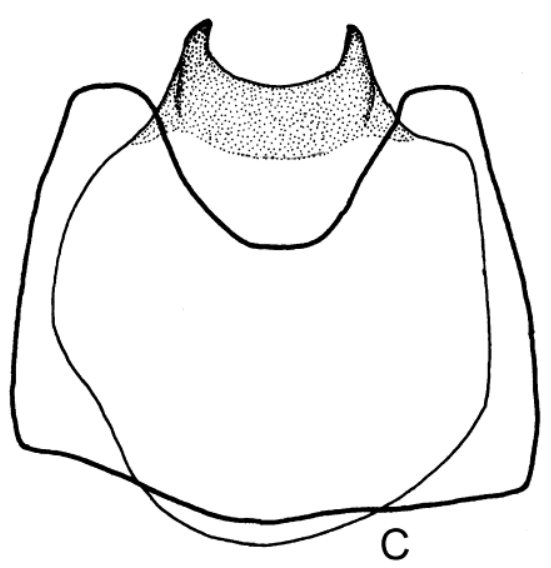

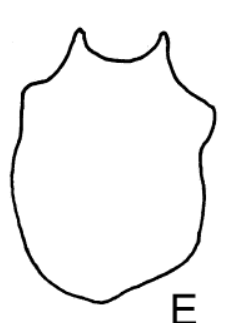

$\mathrm{E}$

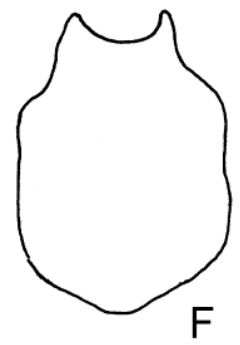

$\mathrm{F}$

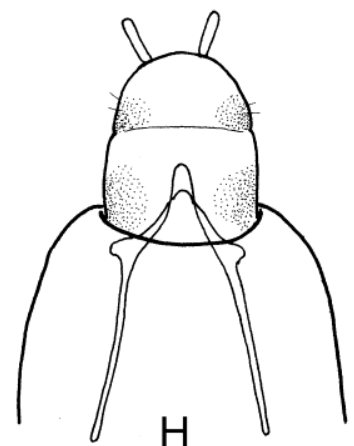

$\mathrm{H}$

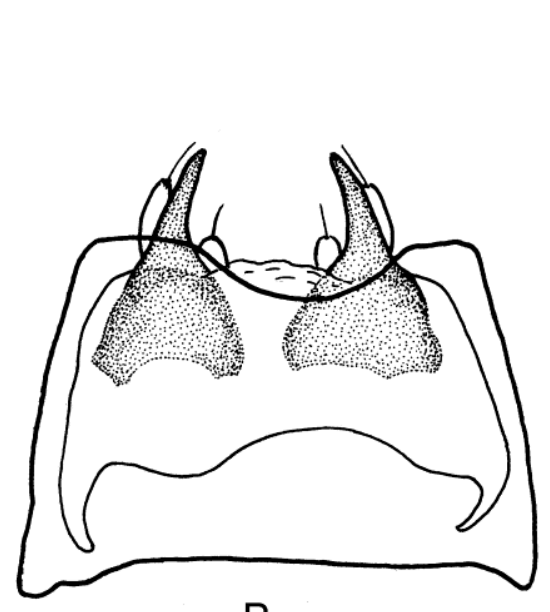

B
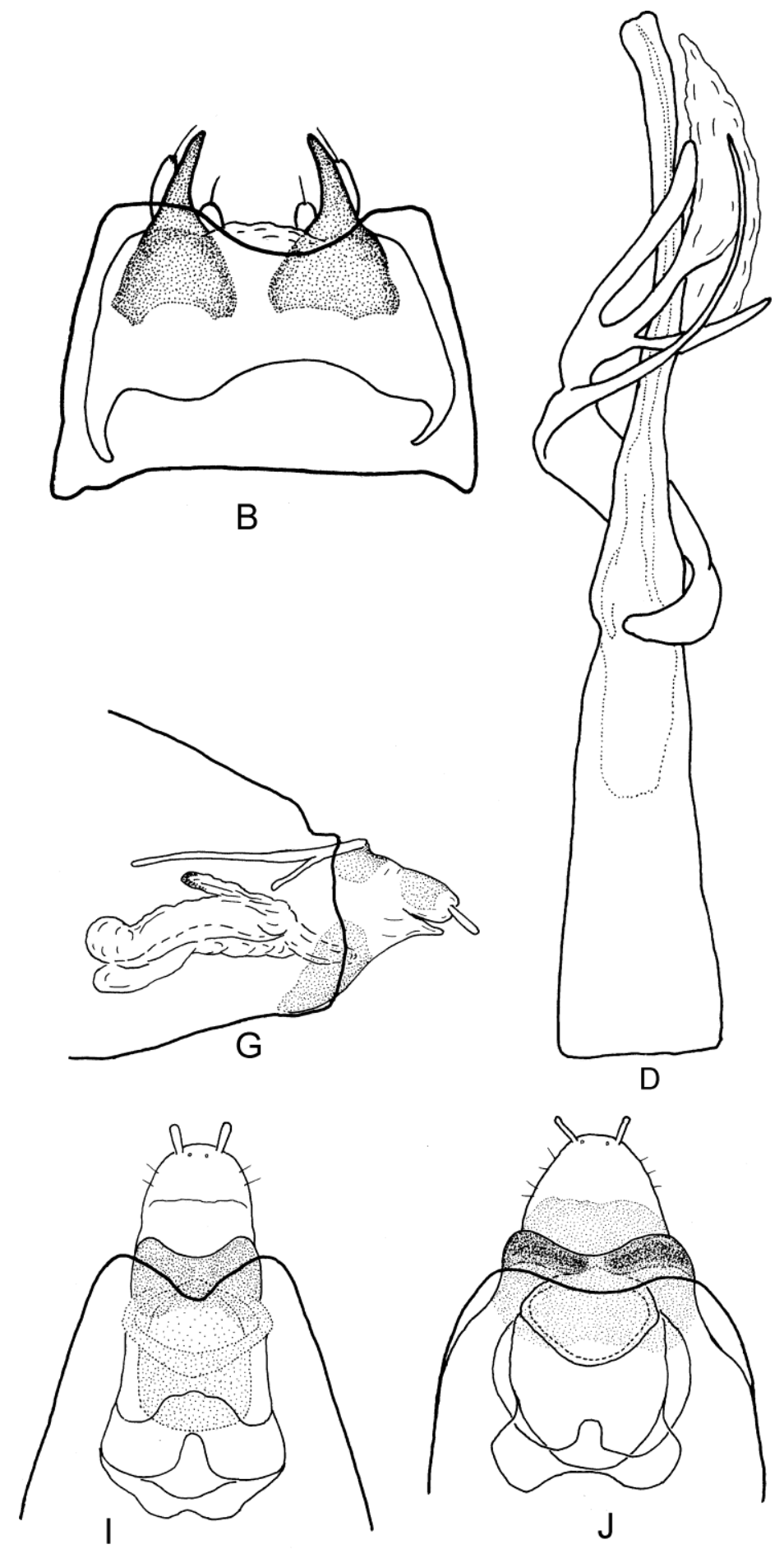

Figure 3. Oxyethira chitosea. Male (A-F): A = genitalia, left lateral; $\mathrm{B}=$ same, dorsal; $\mathrm{C}=$ same, ventral; $\mathrm{D}=$ phallus, ventral; $\mathrm{E}, \mathrm{F}=$ segment IX, ventral. Female $(\mathrm{G}-\mathrm{J})$ : $\mathrm{G}=$ abdominal segments VII-X, lateral; $\mathrm{H}=$ same, dorsal; $\mathrm{I}$ and $\mathrm{J}=$ same, ventral. Materials: A-D, holotype; E, a paratype; F, Lake Akan-panke-ko, Hokkaido; G-I, type locality;

J, Ikeonokôchi-shitsugen, Fukui. 
excide at ventro-posterior margin. Segment IX almost completely enclosed within segment VIII; dorsum shorter than ventrum in lateral view; subquadrate with asymmetrically excised anterior margin in dorsal view; subquadrate with more or less protruded anterior margin in ventral view. Segment $X$ reduced to low membranous lobe. Pair of paraproct heavily sclerotized; triangular with truncate apices in lateral view, thin triangular in dorsal view. Basal plate of gonopods at basoventral margin of paraproct. Gonopods triangle in lateral view, curved dorso-posteriorly, fused to sternite IX at base. Setal lobes at mesal surface of gonopods. Phallic organ with paramere encircling shaft once and split into a filiform and a more complex arm; complex arm split into 3 unequal branches, middle arm longest with expanded membranous blade.

Female. Length of forewing and hind wing $2.9-3.0 \mathrm{~mm}$ and $2.3-2.5 \mathrm{~mm}$, respectively $(\mathrm{n}=5)$. Antennae 25-26 segmented, light brown with 3 dark segments sub-apically and 1.1-1.3 mm long $(\mathrm{n}=5)$. Sternite VI with small acute ventral process. Tergites VIII and X very weakly sclerotized, segment IX membranous. Sternite VIII with brown, large subquadrate sclerite; in ventral view, anterior margin almost straight, posterior margin with middle wide excision; posterior margin heavily sclerotized in Fukui specimens.

Remarks. This species belongs to the tinovae species cluster Oláh and Ito, 2013, the flavicornis species group Kelley, 1984 (Oláh \& Ito 2013), and is similar to O. angustella Martynov, 1933, but clearly discriminated from the later by three branched complex arm of phallic apparatus in male. The female is described here for the first time and characterized by large subqudrate ventral sclerite of segment VIII and 3 dark subapical segments of antennae. However, the females of this species are rather similar to O. angustella as described above and difficult to discriminate from the later if they were deposited in alcohol more than several months.

Distribution (Fig. 12). Hokkaido (Nemuro, Kushiro, Ishikari), Honshu (Fukui).
Habitat. Adults were collected from upper reaches of streams and small lakes in forests.

Japanese name. Chitose-hagoita-himetobikera.

\section{Oxyethira hiroshima Oláh \& Ito, 2013}

(Figures 4, 5, 12)

Oxyethira hiroshima Oláh \& Ito, 2013, 35-36, figs. 29-33, male, Honshu (Hiroshima).

Material examined. Additional records to Oláh \& Ito (2013). Honshu. Aomori: 1 male, Mutsu-shi, Shimo-ogawa, Shozu-gawa, 66 m, 17.ix. 2010, TI, L. Shizuoka: 1 male, Shizuoka-shi, Akazawa, 4.x. 2011, T. Hattori. Shiga: 1 female, Higashi-omi-shi, Eigenji-cho, Kanzaki-gawa, Kazakoshi-zawa, 5.ix. 1998, T. Hattori, L; 5 females, same locality, 6 \& 30.ix.2013, TI, L; 3 males, 2 females, same locality, 9.ix.2014, TI, L \& S; 1 female, same locality, 29.v.2015, S. Okayama: 1 male, Maniwa-shi, Hiruyama, Bessho, Ohara, 15. v.2016, K. Nojima; 3 maels, 4 females, Mimasaka-shi, Takinomiya, 20. vii.2016, K. Nojima.

Adult. Wings light brown with several small lighter markings. Antennae brown to light brown with darker marking near apices. Spur formula 0 , 3,4 .

Male. Length of forewing and hind wing 3.1 $\mathrm{mm}$ and $2.7 \mathrm{~mm}$, respectively $(\mathrm{n}=1)$. Antennae 31 segmented; length $1.8 \mathrm{~mm}(\mathrm{n}=1)$. Apicomesal process of sternite VII short and acute. Segment VIII annular with postero-lateral processes in lateral view, processes heavily sclerotized with spiny apices. Segment IX almost completely enclosed within segment VIII; dorsum shorter than ventrum; oval in dorsal and ventral views. Segment $\mathrm{X}$ reduced to membranous lobe. Pair of paraproct heavily sclerotized, very complex, shape rather variable locally, individually and even in opposite side of a single specimen; in lateral view, consisted of dorsally directed comb-like bar, posteriorly directed thick board with dorso-caudad directed and ventro-caudad directed bars apically; in ventro-posterior view, circular with 2-3 short triangular projections. 

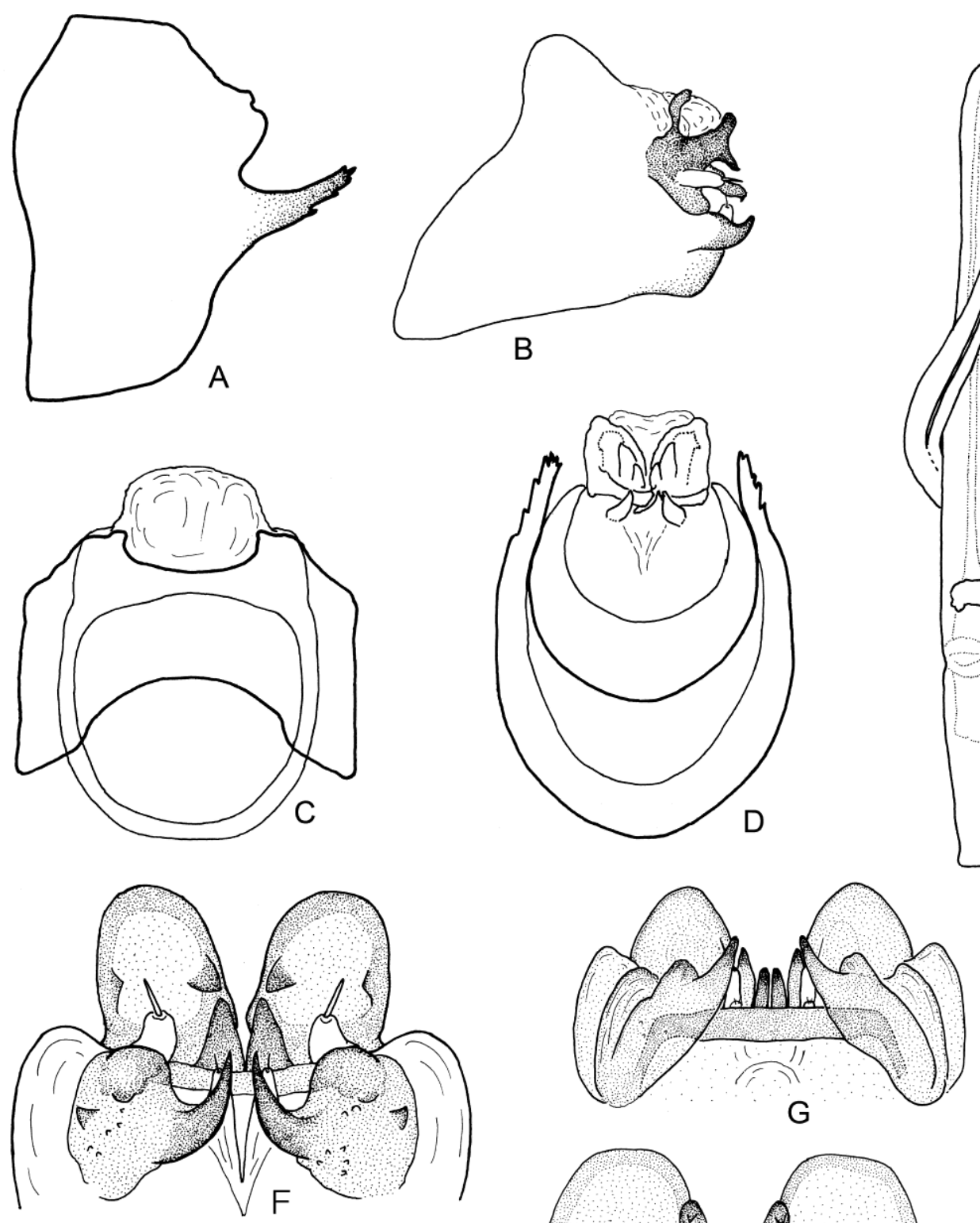

$\mathrm{E}$
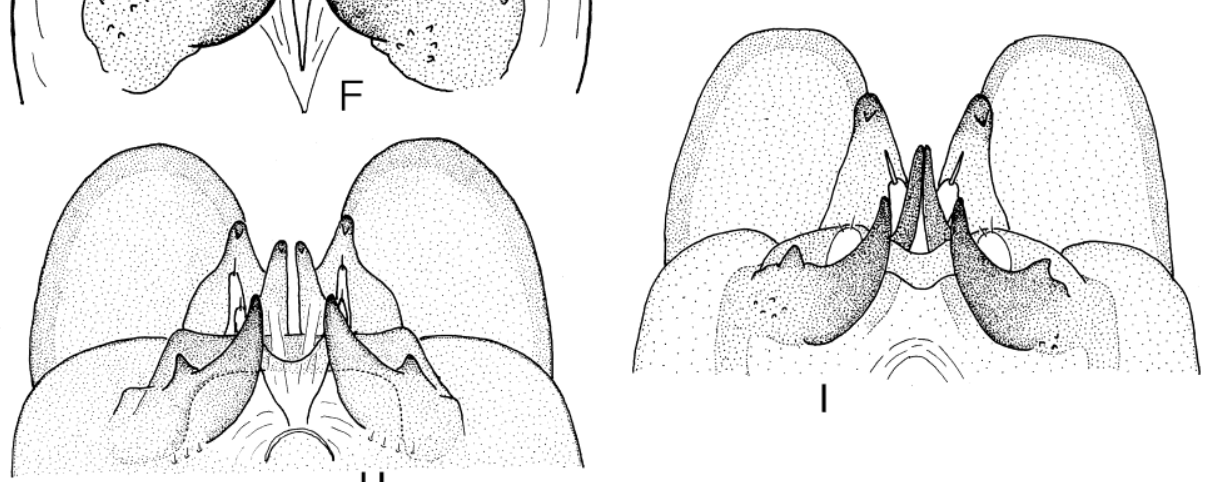

$\mathrm{H}$

Figure 4. Oxyethira hiroshima. Male. A = segment VIII, left lateral; B = genitalia excluding segment VIII, lateral; $\mathrm{C}=$ genitalia, dorsal; $\mathrm{D}=$ same, ventral; $\mathrm{E}=$ phallus, dorsal; $\mathrm{F}-\mathrm{I}=$ ventro-caudal view of genitalia, variation. Materials: A-F, holotype; $\mathrm{G}=$ Shozu-gawa, Aomori; H= Akazawa, Shizuoka; I= Hiruyama, Okayama. 

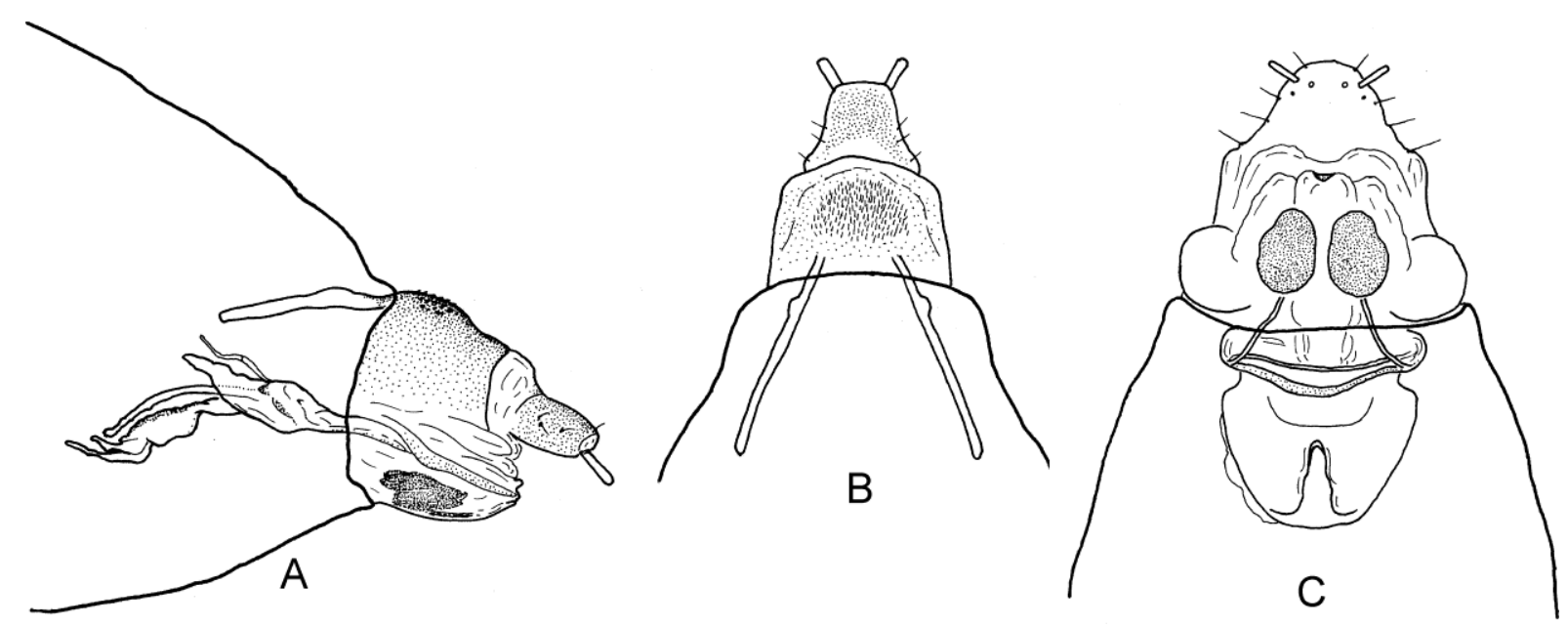

Figure 5. Oxyethira hiroshima. Female. A = segments VII-X, lateral; $\mathrm{B}=$ same, dorsal; $\mathrm{C}=$ same, ventral. Material: Kanzaki-gawa, Shiga.

Basal plate of gonopods at basoventral margin of paraproct. Gonopods triangle, slightly curved dorso-posteriorly in lateral and ventro-posterior views, fused to sternite IX at base. Setal lobes at mesal surface of gonopods. Phallic organ with paramere encircling shaft once and split into 2 arms; 2 arms elongated to posteriorly, shorter than aedeagus; one of arms longer and slender than another.

Female. Length of forewing and hind wing 2.1-2.2 $\mathrm{mm}$ and $1.8-1.9 \mathrm{~mm}$, respectively $(\mathrm{n}=2)$. Antennae 22-23 segmented and 0.8-0.9 mm long $(n=2)$. Sternite VI with small acute apicomesal process. Tergite of VIII weakly sclerotized with assemblage of short spiny setae. Two egg-shaped sclerites on sternite VIII brown, conspicuous. Tergite $\mathrm{X}$ weakly sclerotized.

Remarks. This species belongs to the hiroshima species cluster Oláh and Ito, 2013, the flavicornis species group Kelley, 1984 (Oláh \& Ito 2013), and is distinguished from any other species by the heavily sclerotized complex paraproct. The female is described here for the first time and is characterized by egg-shaped sclerites of sternite VIII. As shown below, the females of O. mekunna Oláh and Ito, 2013, also have egg-shaped sclerites on sternite VIII and difficult to discriminate each other based on the shape.
However, the distributions of the two species are separated at present time (Fig. 12).

Distribution (Fig. 12). Honshu (Aomori, Shizuoka, Shiga, Okayama, Hiroshima).

Habitat. Adults were collected near hygropteric zones and small rapid streams.

Japanese name. Hiroshima-hagoita-himetobikera (newly given here).

\section{Oxyethira mekunna Oláh \& Ito, 2013}

(Figures 6, 12)

Oxyethira mekunna Oláh \& Ito, 2013, 36-37, figs. 34-38, male, Hokkaido (Tokachi, Kamikawa, Sorachi, Shiribeshi).

Material examined. Additional records to Oláh \& Ito (2013). Hokkaido: 9 males, Kami-shihorocho, Tokachi-mitsumata, 13.vii.1996, A. Ohkawa; 1 female, Horokanai-cho, Shumarinai, Shumarinai-gawa, small tributary, 21.viii.2014, TI, S; 1 male, 1 female, same locality, 19.vi.2015, TI, S \& L; 1 male, Uryu-numa, Uryu-cho, 4-6.viii.1976, T. Hattori, L (mounted on slide); 48 males, $15 \mathrm{fe}-$ males, Iwanai-cho, Mekunnai-shitsugen, 1.viii. 1998, M. Ōhara; 29 males, 5 females, Iwanai-cho, Penke-mekunnai-shitsugen, 13.vii.1998, A. Yamamoto et al. 

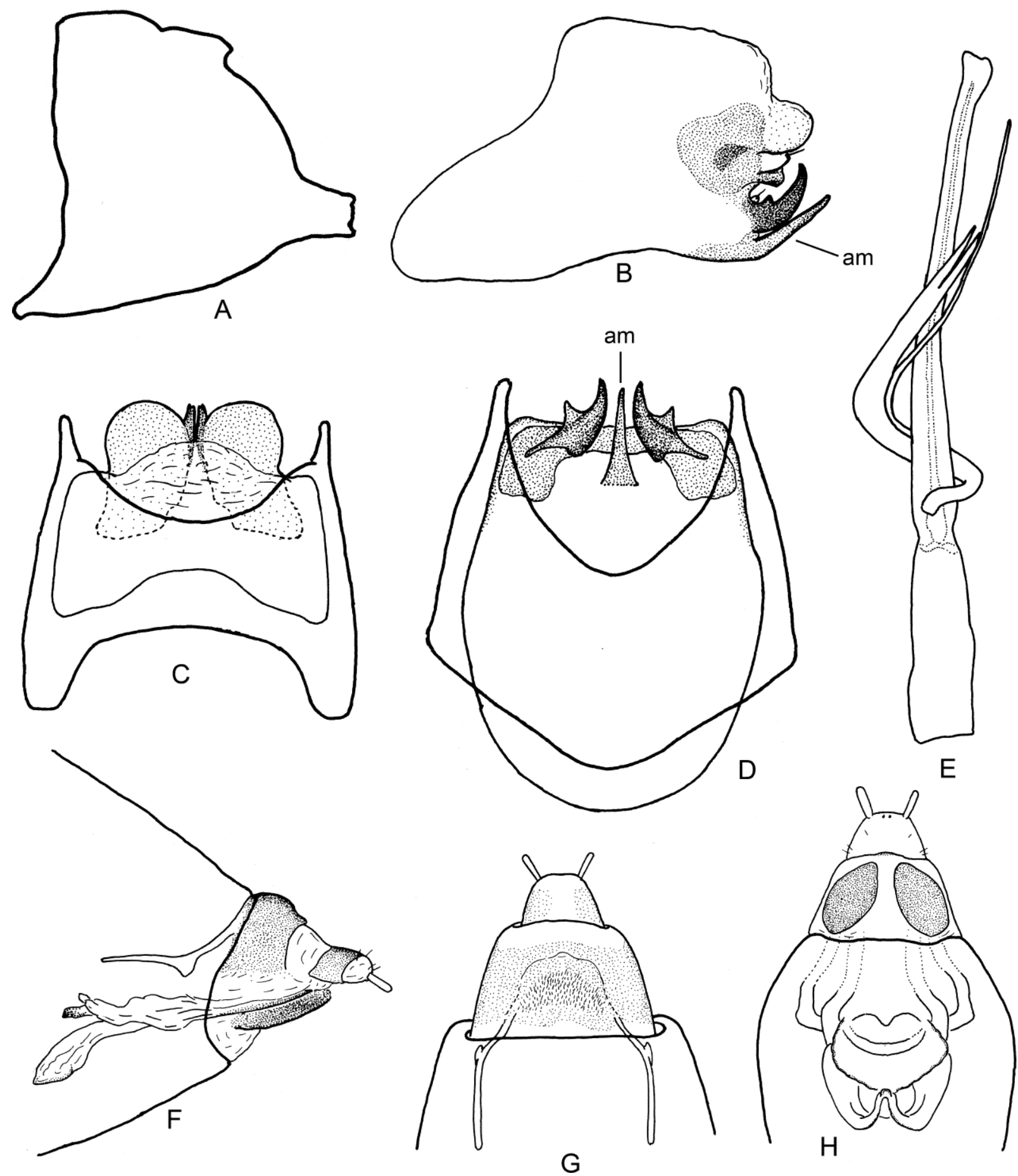

Figure 6. Oxyethira mekunna. Male (A-E): A = segment VIII, left lateral; B = genitalia excluding segment VIII, left lateral; $\mathrm{C}=$ genitalia, dorsal; $\mathrm{D}=$ same, ventral; $\mathrm{E}=$ phallus, dorsal. Female $(\mathrm{F}-\mathrm{H}): \mathrm{F}=$ abdominal segments VII-X, lateral; $\mathrm{G}=$ same, dorsal; $\mathrm{H}=$ same, ventral. Materials: A-E, holotype; $\mathrm{F}-\mathrm{H}$, type locality. Abbreviations: am, apicomesal process of segment IX. 
Adult. Wings light brown with several small lighter markings. Antennae brown to light brown with darker marking at half way and near apices. Spur formula $0,3,4$.

Male. Length of forewing and hind wing $2.5-2.7 \mathrm{~mm}$ and $2.0-2.4 \mathrm{~mm}$, respectively $(\mathrm{n}=5)$. Antennae 26-31 segmented; length $1.3-1.6 \mathrm{~mm}$ $(n=5)$. Apicomesal process of sternite VII short and acute. Segment VIII annular, dorsum slightly shorter than ventrum, with postero-lateral processes in lateral view, processes slightly sclerotized, quadrate; wide large excisions at anterior and posterior margins in dorsal view; largely convex at anterior margin and largely excised at posterior margin in ventral view. Segment IX almost completely enclosed within segment VIII; dorsum distinctly shorter than ventrum; broad subquadrate in dorsal view and oval with apicomesal long process (am) in ventral view. Segment $\mathrm{X}$ reduced to low membranous lobe. Pair of paraproct seimi-circular with short barlike ventral projections in lateral and dorsal views. Basal plate of gonopods near baso-lateral margin of paraproct. Gonopods triangle with low acute blade at dorso-lateral margin, curved dorso-posteriorly in lateral and ventral views, fused to sternite IX at base. Short setal lobes at mesal surface of gonopods. Phallic organ with paramere encircling shaft once and split into a filiform and tape-like arm; tape-like arm bifid at apical 1/5; filiform longer than tape-like arm but shorter than aedeagus.

Female. Length of forewing and hind wing $2.4-2.5 \mathrm{~mm}$ and $2.0-2.4 \mathrm{~mm}$, respectively $(\mathrm{n}=5)$. Antennae 25 segmented and $1.3 \mathrm{~mm}$ long $(\mathrm{n}=1)$. Sternite VI with small acute apicomesal process. Tergite of VIII weakly sclerotized with assemblage of short spiny setae. Two ellipsoidal or egglike sclerites on sternite VIII brown, conspicuous. Segment IX membranous and tergite $\mathrm{X}$ weakly sclerotized.

Remarks. This is a species of the hiroshima species cluster Oláh and Ito, 2013, the flavicornis species group Kelley, 1984 (Oláh \& Ito, 2013) and distinguished from other Japanese species by apicomesal long process of sternite IX and dorso-lateral acute lobe of gonopods in male. The female is described here for the first time and is characterized by ellipsoidal or egg-like sclerites of sternite VIII, but difficult to discriminate from $O$. hiroshima as described above, if males are not collected at same site.

Distribution (Fig. 12). Hokkaido (Tokachi, Kamikawa, Sorachi, Shiribeshi).

Habitat. Most adults were collected from marshes and small streams in forests.

Japanese name. Mekunna-hagoita-himetobikera (newly given here).

\section{Oxyethira miea Oláh \& Ito, 2013}

(Figures 7, 12)

\section{Oxyethira miea Oláh \& Ito, 2013, 42-43, figs. 53-56,} male, Honshu (Mie).

Material examined. Additional records to Oláh \& Ito (2013). Honshu. Shizuoka: 1 male, Shizuoka-shi, Nyujima, 9.ix.2008, T. Hattori. Aichi: 15 males, 75 females, Shinshiro-shi, Toyooka, Ichinose, Ōtsutani-gawa, 29.vi.2013-17.viii.2014, H. Nishimoto et al., L (2 males, 11 females, 29.vi. 2013; 8 males, 49 females, 18.vii.2013; 7 females, 20.ix.2013; 5 males, 8 females, 17.viii.2014); 1 female, Shinshiro-shi, Tsukuride-moriyoshi, Tokaizu-gwa, 22.ix.2013, H. Nishimoto. Shiga: 1 male, Higashi-omi-shi, Eigenji-cho, Kanzakigawa, 5.ix.1998, T. Hattori.

Adult. Wings light brown with several small lighter markings. Antennae brown to light brown with darker marking at half way and near apices. Spur formula 0, 3, 4 .

Male. Length of forewing and hind wing $2.0-2.7 \mathrm{~mm}$ and $1.9-2.3 \mathrm{~mm}$, respectively $(\mathrm{n}=5)$. Antennae 32-35 segmented; length 1.5-1.6 mm $(\mathrm{n}=2)$. Apicomesal process of sternite VII short and acute. Segment VIII annular, with short acute projections at middle of anterior margin and 


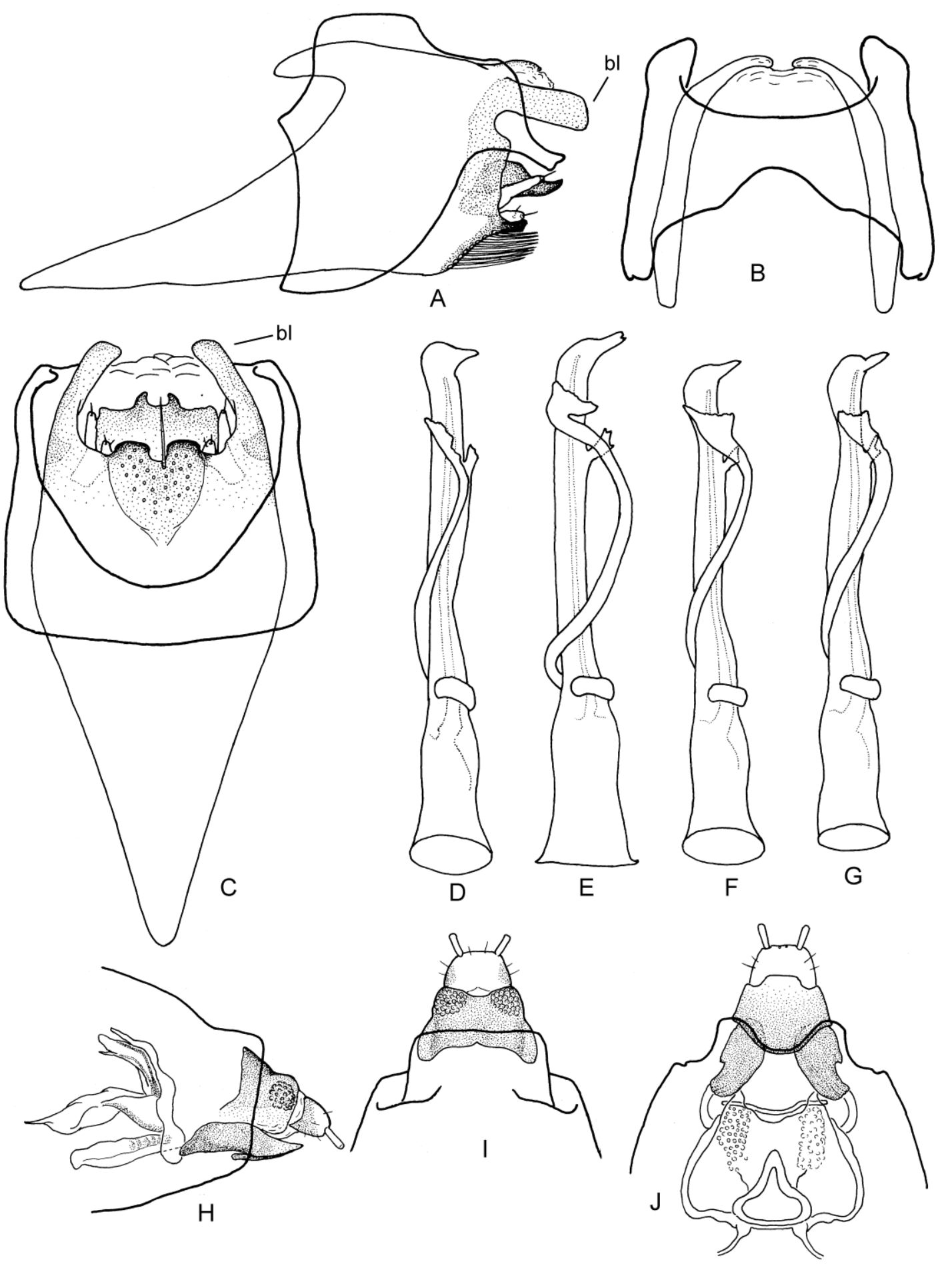

Figure 7. Oxyethira miea. Male $(\mathrm{A}-\mathrm{G})$ : $\mathrm{A}=$ genitalia, left lateral; $\mathrm{B}=$ same, dorsal; $\mathrm{C}=$ same, ventral; $\mathrm{D}-\mathrm{G}=$ phallus, dorsal. Female (H-J): H= abdominal segments VII-X, lateral; I= same, dorsal; J= same, ventral. Materials: A-D, holotype; E, Kanzaki-gawa, Shiga; F, Nyujima, Shizuoka; G-J, Ōtsutani-gawa, Aichi. Abbreviations: bl, board-like lobe of segment IX. 
subquadrate projections at middle of posterior margin in lateral view. Segment IX almost enclosed within VII-VIII; ventrum very long reaching to end of segment VI, narrowing in lateral and ventral views; dorsum short band producing short dorsolateral narrowing lobes anteriorly and large board-like lobes posteriorly in dorsal view; boardlike lobes curved mesally in ventral view. Segment $\mathrm{X}$ reduced to low membranous lobe. Pair of paraproct triangle, slightly curved dorsally in lateral view; fused at basal $4 / 5$, subquadrate with small acute process at posterior margin in ventral view. Basal plate of gonopods near baso-lateral margin of paracropt. Gonopods fused to sternite IX at base, heavily sclerotized, short truncate lobes in ventral view, with many thick setae. Short setal lobes at mesal surface of gonopods. Phallic organ with paramere encircling shaft once and armed with serrated lobe apically; serrated lobe variable in size locally and individually; aedeagus with a small truncate process at $1 / 5$ way from apex and with heavily sclerotized short beak-shaped process apically; shapes of small truncate process and beak-shaped process slightly variable locally.

Female. Length of forewing and hind wing 2.2-2.7 $\mathrm{mm}$ and $1.9-2.7 \mathrm{~mm}$, respectively $(\mathrm{n}=5)$. Antennae 26-27 segmented and 1.0-1.2 mm long $(n=4)$. Sternite VI with small acute apicomesal process. Tergite VIII weakly sclerotized with assemblages of granules posterolaterally. Sclerite of sternite VIII pentagon-shaped with gently convex anterior margin and squarely convex posterior margin in ventral view. Two ellipsoidal sclerites connected to sternite VIII antero-laterally, slightly curved laterally with excise at outer margin in ventral view. Segment IX membranous and tergite $\mathrm{X}$ weakly sclerotized.

Remarks. This is a species of the ramosa species group Kelley, 1984 (Oláh \& Ito 2013), and is distinguished from other species by short truncate gonopods with thick and long setae, paramere with serrated apex and aedeagus with truncate lobe subapically in male. In the original description, small subapical truncate lobe of male aedeagus is incorrectly figured on the paramere
(Oláh \& Ito 2013 fig. 56) but the lobe is on subapical part of aedeagus. The female is described here for the first time and characterized by pentagon-shaped sclerite of sternite VIII.

Distribution (Fig. 12). Honshu (Shizuoka, Aichi, Mie, Shiga).

Habitat. Adults were collected from beside streams.

Japanese name. Mie-hagoita-himetobikera (newly given here).

\section{Oxyethira okinawa Oláh \& Ito, 2013}

(Figures 8, 12)

Oxyethira okinawa Oláh \& Ito, 2013, 43-44, figs. 57-60, male, Ryukyu Islands (Okinawa-jima); Kuhara \& Ito, 2017, 16, Ryukyu Islands (Yakushima).

Oxyethira sp.: Shimura et al., 2014, 45, Ryukyu Islands (Amami-oshima).

Material examined. Additional records to Oláh \& Ito (2013). Ryukyu Islands. Yakushima: 1 male, 3 females (detail data in Kuhara \& Ito, 2017). Amami-oshima: 3 females, Yamato-son, Materiagawa, 27.iii.2014, N. Shimura; 7 females, same locality, 21.x.2014, TI, L \& S. Okinawa-jima: 5 females, Nago-shi, Genka-kawa, Hogen-hashi (type locality), 17-19.x.2014, TI, L \& S; 1 female, Nago-shi, Teima-gawa, 14.ix.1990, TI; 11 females, Kunigami-son, Yona-gawa, Nakafukujihashi, 18.x.2014, TI, L; 1 male, Kunigami-son, Nishime-dake, headwater of Zatsun-gawa, 28.vii. 1997, R. B. Kuranishi (deposited in the personal collection of R. B. Kuranishi).

Adult. Wings light brown with several small lighter markings. Antennae brown to light brown with darker marking at half way and near apices. Spur formula 0, 3, 4 .

Male. Length of forewing and hind wing 2.1-2.7 $\mathrm{mm}$ and 2.0-2.6 mm, respectively $(\mathrm{n}=3)$. Antennae segments 36 , length $2.8 \mathrm{~mm}(\mathrm{n}=1)$. Apicomesal process of sternite VII short and acute. Segment VIII annular, with low subacute projecti- 


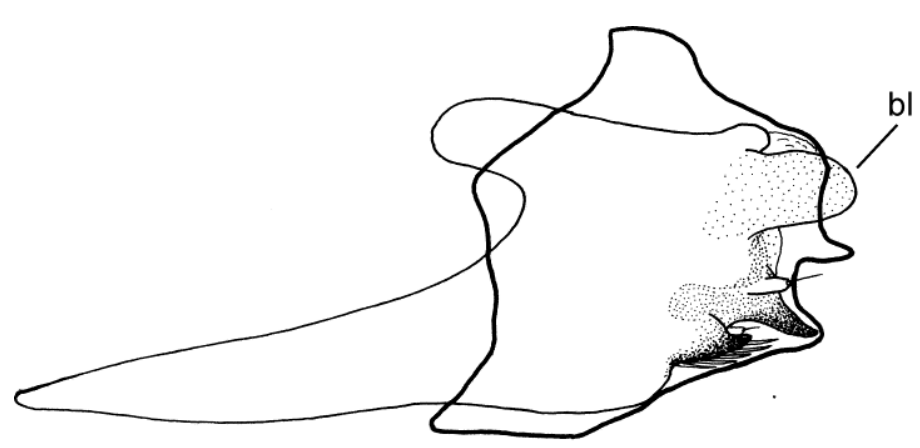

A
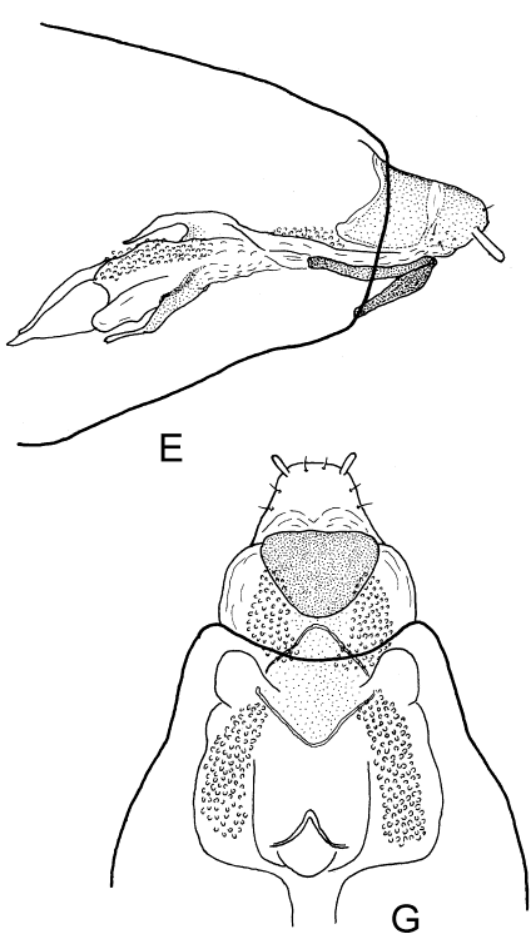

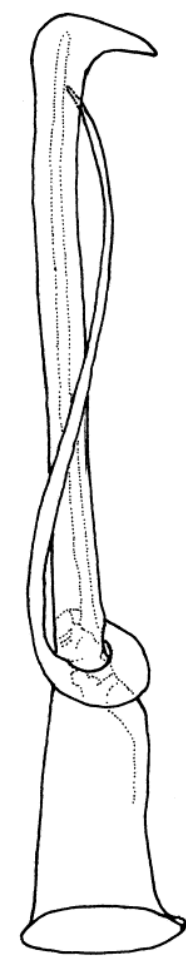

D
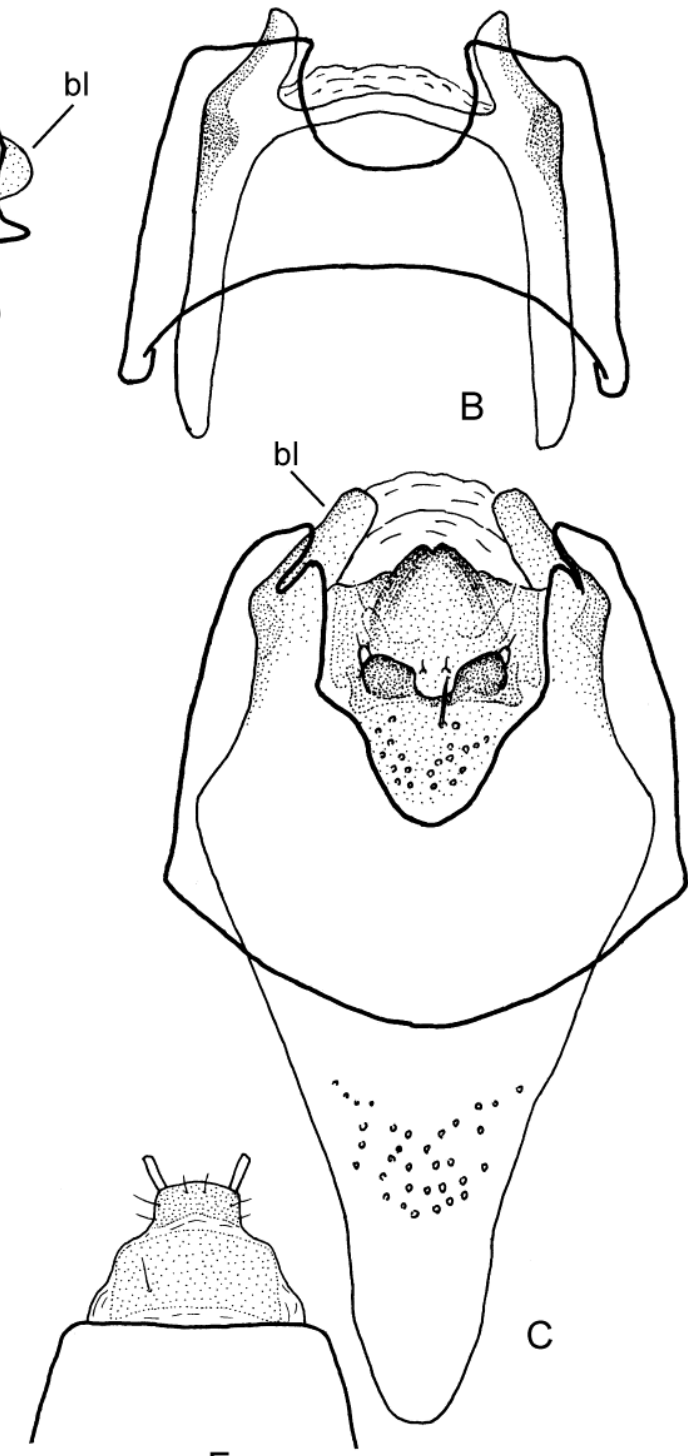

$\mathrm{F}$

Figure 8. Oxyethira okinawa. Male (A-D): A = genitalia, left lateral; B = genitalia, dorsal; $\mathrm{C}=$ same, ventral; $\mathrm{D}=$ phallus, dorsal. Female $(\mathrm{E}-\mathrm{G})$ : $\mathrm{E}=$ abdominal segments VII-X, lateral; $\mathrm{F}=$ same, dorsal; $\mathrm{G}$ = same, ventral. Materials: A-D, holotype; E-G, type locality. Abbreviations: bl, board-like lobe of segment IX.

ons at middle of anterior and posterior margins in lateral view; subquadrate with large round excision at posterior margin in dorsal view; subquadrate with deep wide excision at posterior margin in ventral view. Segment IX almost enclosed within VII-VIII; ventrum very long reaching to end of segment VI, narrowing in lateral and ventral views; dorsum short band producing long dorsolateral lobes anteriorly and board-like lobes posteriorly in dorsal view; board-like lobes direct- ed postero-mesad in dorsal and ventral views. Segment $X$ reduced to short membranous lobe. Pair of paraproct triangle in lateral view; almost completely fused each other with middle small excision posteriorly in ventral view. Basal plate of gonopads near baso-lateral margin of paracropt. Gonopods heavily sclerotized, small, fused to sternite IX at base, triangular in lateral view and truncate lobes in ventral view, with many thick setae. Short setal lobes at mesal surface of gono- 
pods. Phallic organ with paramere encircling shaft once; aedeagus with heavily sclerotized short beak-shaped process apically; paramere slender, shorter than aedeagus.

Female. Length of forewing and hind wing $2.2-2.6 \mathrm{~mm}$ and $1.7-2.4 \mathrm{~mm}$, respectively $(\mathrm{n}=5)$. Antennae 25-26 segmented and 0.8-1.2 mm long $(n=5)$. Sternite VI with small acute apicomesal process. Tergites of VIII and $\mathrm{X}$ weakly sclerotized, segment IX membranous. Sternite VIII with large subtriangular sclerite in ventral view. Many granules on inner apparatus.

Remarks. This is a species of the ramosa species group Kelley, 1984 (Oláh \& Ito 2013), and similar to $O$. miea Oláh \& Ito, 2013, but distinguished from the later by triangular paraprocts largely fused each other at base and simply elongated paramere in male. The female is described here for the first time and characterized by subtriangular sclerite on sternite VIII.

Distribution (Fig. 12). Ryukyu Islands (Yakushima, Amami-oshima, Okinawa-jima).

Habitat. Adults were collected beside streams.

Japanese name. Okinawa-hagoita-himetobikera.

\section{Oxyethira ozea Oláh \& Ito, 2013}

(Figures 9, 12)

Oxyethira ozea Oláh \& Ito, 2013, 41-42, figs. 50-52, male, Honshu (Gunma).

Material examined. Holotype male, Gunma, Oze, Yamanohama, 1400 m, 2.ix.1996, T. Nozaki, L.

Adult. Wings light brown with several small lighter markings. Antennae brown to light brown with darker marking at half way and near apices. Spur formula 0, 3, 4 .
Male. Length of forewing and hind wing 2.5 $\mathrm{mm}$ and $2.0 \mathrm{~mm}$, respectively $(\mathrm{n}=1)$. Antennae 29, 31 segmented (left and right one with differently segmented) and $1.6 \mathrm{~mm}(\mathrm{n}=1)$. Apicomesal process of sternite VII short and acute. Segment VIII annular, with large triangular postero-lateral projections and small subacute projections in lateral view; circular with subacute excision at anterior margin and large round excision at posterior margin in dorsal view; circular with deep wide excision at posterior margin in ventral view. Segment IX almost enclosed within VIII; ventrum longer than dorsum; dorsum short band with concave anterior and posterior margins in dorsal view; sternite with oval anterior margin and almost straight posterior margin in ventral view. Segment X reduced to large membranous lobe. Pair of paracropt triangle, gently curved ventroposteriorly in lateral view; thin triangle, fused each other at base in ventral view. Basal plate of gonopods near baso-lateral margin of paracropt. Gonopods sclerotized, triangle, slightly curved dorsally in lateral view; triangle and fused to sternite IX at base in ventral view. Short setal lobes at mesal surface of gonopods. Phallic organ with paramere encircling shaft once; aedeagus with pair of sclerotized spine-like structures subapically.

\section{Female. Unknown.}

Remarks. This is a species of the grisea Group Kelley, 1984, and distinguished from other Japanese species by pair of sclerotized spine-like structures of aedeagus.

Distribution (Fig. 12). Honshu (Gunma). Known only from the type locality.

Habitat. Adult was collected in a highland marsh.

Japanese name. Oze-hagoita-himetobikera (newly given here). 

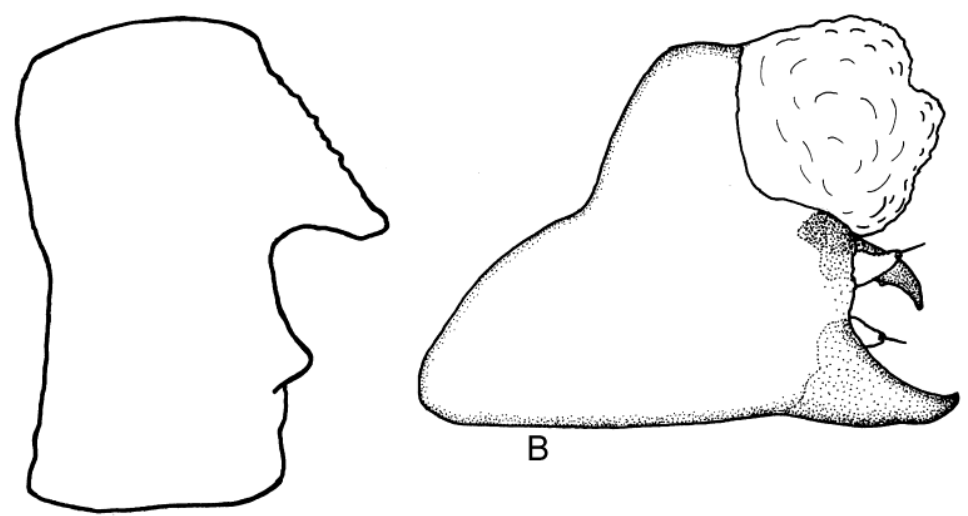

A
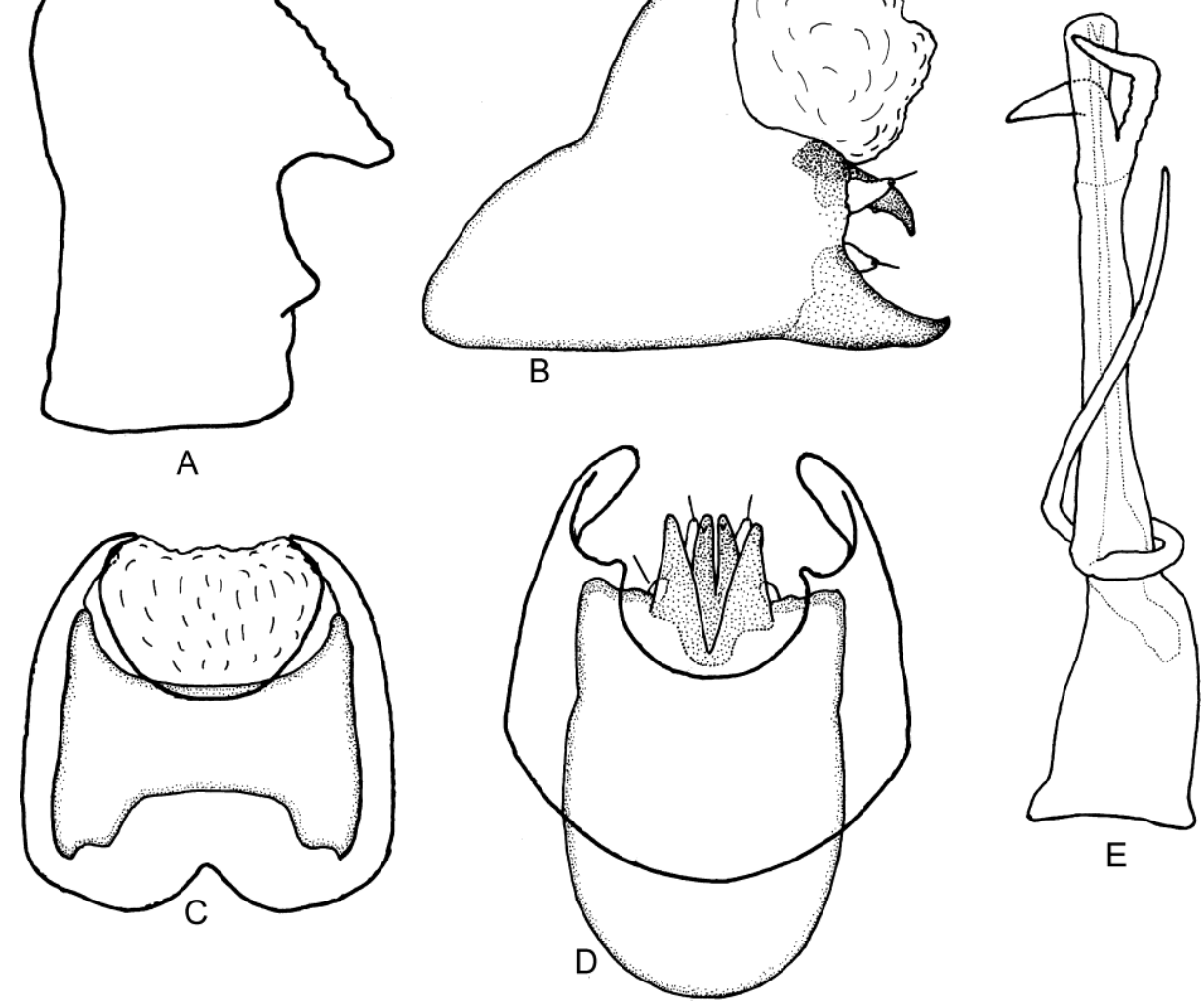

E

Figure 9. Oxyethira ozea. Male. A = segment VIII, left lateral; B = genitalia excluding segment VIII, left lateral; $\mathrm{C}=$ genitalia, dorsal; $\mathrm{D}=$ same, ventral; $\mathrm{E}=$ phallus, left lateral. Material: holotype.

\section{Oxyethira tsuruga sp. nov.}

(Figures 10, 12)

Oxyethira sp., Ito, 2017, 3, Honshu (Fukui).

Holotype male, Honshu, Fukui, Tsuruga-shi, Ikenokôchi Marsh, $\left(35^{\circ} 40^{\prime} \mathrm{N}, 136^{\circ} 08^{\prime} \mathrm{E}, 300 \mathrm{~m}\right.$ above sea level), 11.vi.2016, TI, L (CBM-ZI 164638). Paratypes. 4 males 5 females, same data as holotype (CBM-ZI 164639-164647).

Other specimens examined. 67 males, $581 \mathrm{fe-}$ males, same data as holotype. Hokkaido: 1 male, Kushiro-shi, Akan-cho, Ibeshibetsu-gawa, near small marsh, 27.vii.1999, TI, L.

Diagnosis and remarks. Male of this species resembles to those of Oxyethira ozea Oláh \& Ito
2013, described from central Honshu, and $O$. lumosa Ross, 1948, distributed in southeastern North America (Kelly 1985), in having relatively large membranous lobe of segment $\mathrm{X}$, triangular paracropt and triangular gonopods. However, $O$. tsuruga is distinguished by the shape of segment VIII from the two latter as follows: postero-lateral margin of segment VIII with quadrate projections in $O$. tsuruga ( $c f$. with triangle projections in $O$. ozea and with no projection in O. lumosa); postero-ventral margin of segment VIII with large subtriangle excision in $O$. tsuruga ( $c f$. with large circular excision in $O$. ozea and with very shallow excision in $O$. lumosa). Moreover, O. tsuruga is different from $O$. ozea in the shape of aedeagus as follows; with a very short apical spine in $O$. tsuruga ( $c f$. with 2 subapical spines in O. ozea). This species belongs to the grisea species group Kelley, 1984. 
Adult. Wings light brown with several small lighter markings. Antennae brown to light brown with darker marking at half way and near apices. Spur formula $0,3,4$.

Male. Length of forewing and hind wing 2.4$2.6 \mathrm{~mm}$ and $2.0-2.3 \mathrm{~mm}$, respectively $(\mathrm{n}=6)$. Antennae segments 38 , length $2.0 \mathrm{~mm}(\mathrm{n}=1)$. Apicomesal process of sternite VII short and acute. Segment VIII annular, subquadrate with large quadrate projections at posterior margin in lateral view; large circular excision at posterior margin and almost straight anterior margin in dorsal view; with middle deep subacute excision at ventro-posterior margin and circular anterior margin in ventral view. Segment IX almost completely enclosed in segment VIII; ventrum longer than dorsum, anterior margin circularly convex in ventral view and circularly concave in dorsal view. Segment $X$ reduced to relatively large membranous lobe. Pair of paracropt triangle, heavily sclerotized; strongly curved ventro-posteriorly in lateral view; triangle, strongly curved venro-mesally in ventral view. Basal plate of gonopods near baso-lateral margin of paracropt. Gonopods sclerotized, triangle, apical $1 / 3$ strongly curved dorsally in lateral view; triangle and fused to sternite IX basally in ventral view. Short setal lobes at mesal surface of gonopods. Phallic organ with paramere twice encircling shaft; aedeagus ax-like with short submesal spine apically.

Female. Length of forewing and hind wing $2.9-3.0 \mathrm{~mm}$ and $2.3-2.6 \mathrm{~mm}$, respectively $(\mathrm{n}=5)$. Antennae 25 segmented and 1.2-1.4 mm long $(n=5)$. Sternite VI with small acute apicomesal process. Tergites VIII weakly sclerotized with setose lobe at middle. Segment IX membranous and tergite $\mathrm{X}$ weakly sclerotized. Pair of large round sclerites and transversely long sclerite conspicuous in venter VIII.

Etymology. The name "tsuruga" is a noon in apposition, coined from the type locality.

Distribution (Fig. 12). Hokkaido (Kushiro), Honshu (Fukui).
Habitat. Adults were collected from small marshes.

Japanese name. Tsuruga-hagoita-himetobikera.

\section{Oxyethira shumari sp. nov.}

(Figs. 11, 12)

Holotype male, Hokkaido, Horokanai-cho, Shumarinai, Shumarinai-gawa River, a small tributary $\left(44^{\circ} 17^{\prime} 56^{\prime \prime} \mathrm{N}, 142^{\circ} 09^{\prime} 31^{\prime \prime}\right.$ E, $270 \mathrm{~m}$ above sea level), 3.viii.2016, TI, L (CBM-ZI 164648). Paratypes. 1 male, same data as holotype (CBM-ZI 164649).

Other specimens examined. 24 females, same data as holotype.

Diagnosis and remarks. Male of this species is discriminated from other congeneric species by strongly sclerotized paracropt directed ventromesad, gonopods direcred posteriod, aedeagus with long acute apex and 1.5 times curled paramere. This species belongs to subgenus Oxyethira but the species group is unknown.

Adult. Wings, antennae and body brown to light brown. Spur formula 0, 3, 4.

Male. Length of forewing and hind wing 2.5$2.6 \mathrm{~mm}$ and $2.0 \mathrm{~mm}$, respectively $(\mathrm{n}=2)$. Segments and length of antennae indistinct due to specimen condition. Apicomesal process of sternite VII short and acute. Segment VIII annular, with short spines lined at middle of postero-dorsal corner and postero-lateral margin in lateral view; shallow quadrate excision at posterior margin in dorsal view; middle deep and large subacute or semicircular excision at posterior margin in ventral view. Segment IX almost completely enclosed in segment VIII; ventrum longer than dorsum; anterior margin undulate in lateral view, with middle circular excision in dorsal view; with largely protruded anterior margin in ventral view. Segment $\mathrm{X}$ reduced to relatively large membranous lobe. Pair of paracropt triangle, heavily 

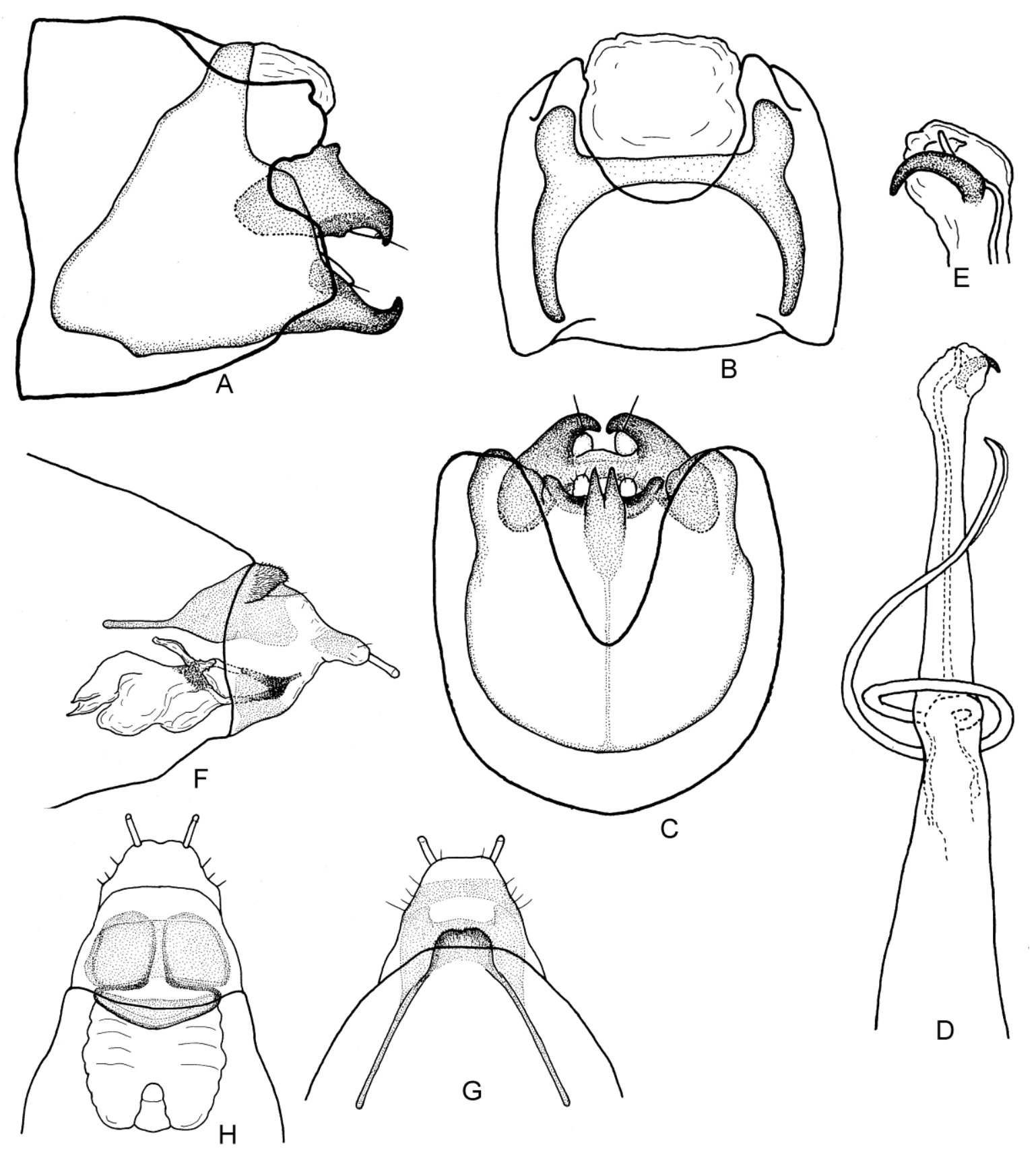

Figure 10. Oxyethira tsuruga. Male (A-E): A = genitalia, left lateral; $\mathrm{B}=$ same, dorsal; $\mathrm{C}=$ same, ventral; $\mathrm{D}=$ phallus, lateral; $\mathrm{E}=$ apex of phallus, ventro-lateral. Female $(\mathrm{F}-\mathrm{H}): \mathrm{F}=$ abdominal segments VII-X, lateral; $\mathrm{G}=$ same, dorsal; $\mathrm{H}=$ same, ventral. Materials: A-E, holotype; $\mathrm{F}-\mathrm{H}$, type locality.

sclerotized; strongly curved ventro-posteriorly in lateral view, strongly curved mesally in ventral view. Basal plate of gonopods near baso-lateral margin of paracropt. Gonopods sclerotized, triangular, directed posteriod; apical 1/4 slightly curved laterally in ventral view. Short setal lobes at mesal surface of gonopods. Phallic organ with paramere 1.5 times encircling shaft; aedeagus slightly thickened at apical $1 / 7$, then gradually narrowing with acute apex. 
Female. Length of forewing and hind wing $2.3-2.8 \mathrm{~mm}$ and $2.0-2.3 \mathrm{~mm}$, respectively $(\mathrm{n}=5)$. Antennae 22-23 segmented and 0.9-1.0 mm long $(\mathrm{n}=3)$. Sternite VI with small acute apicomesal process. Tergites VIII and X weakly sclerotized, segment IX membranous. Weakly sclerotized rectangular plate in venter VIII. Roundish sclerite and horizontal lamella conspicuous.

Etymology. The name "shumari" is a noon in apposition, coined from the type locality.

Distribution (Fig. 12). Hokkaido (Kamikawa). Only known in the type locality.

Habitat. Adults were collected from a small stream.

Japanese name. Shumari-hagoita-himetobike-
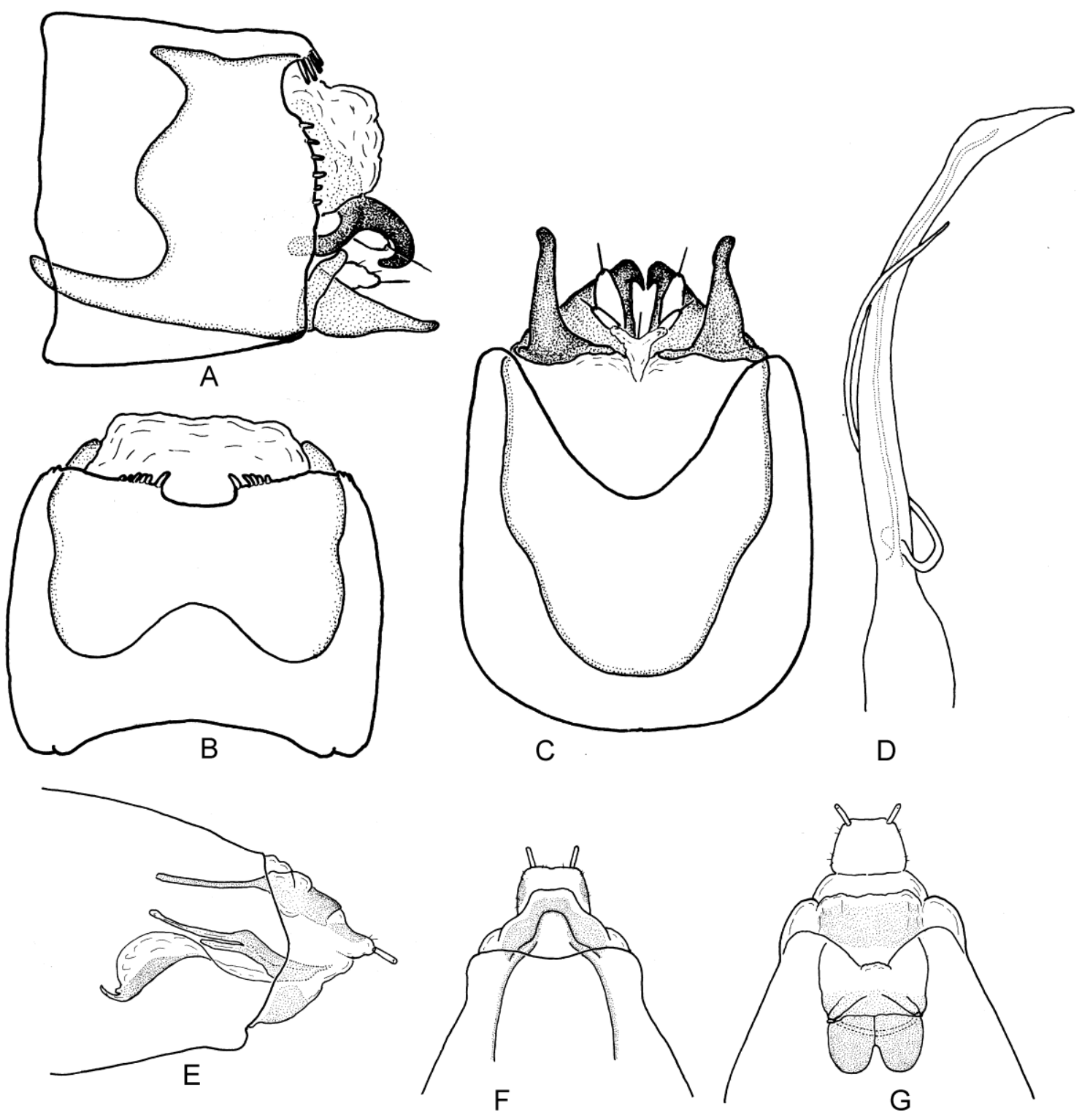

Figure 11. Oxyethira shumari. Male (A-D): A = genitalia, left lateral; $\mathrm{B}=$ genitalia, dorsal; $\mathrm{C}=$ same, ventral; $\mathrm{D}=$ phallus, dorso-lateral. Female $(\mathrm{E}-\mathrm{G})$ : E = abdominal segments VII-X, lateral; $\mathrm{F}=$ same, dorsal; $\mathrm{G}=$ same, ventral. Materials: A-D, holotype; E-G, type locality. 

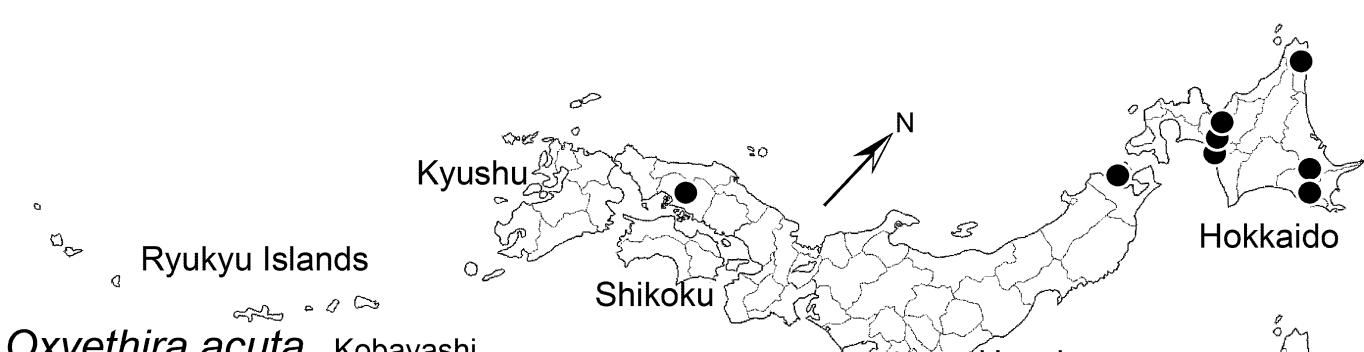

- Oxyethira acuta Kobayashi

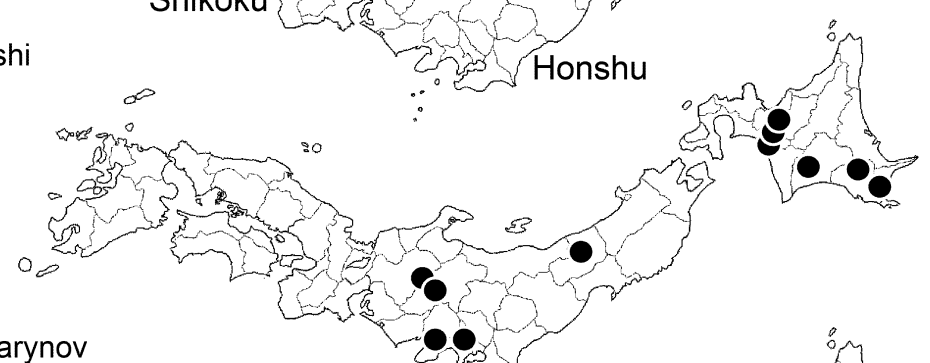

- Oxyethira angustella Marynov
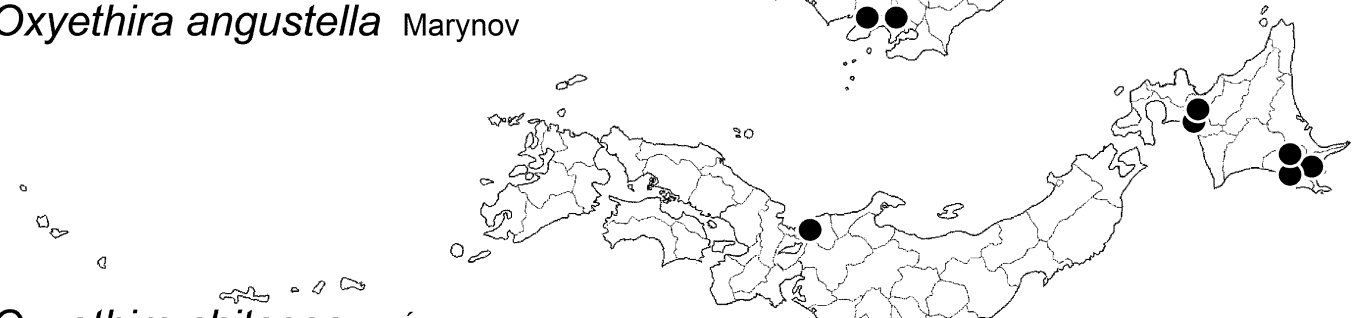

- Oxyethira chitosea Oláh \& Ito

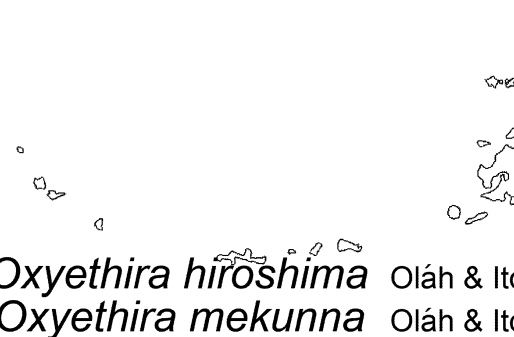

- Oxyethira hirroshimima oláh \& Ito

- Oxyethira mekunna Oláh \& Ito
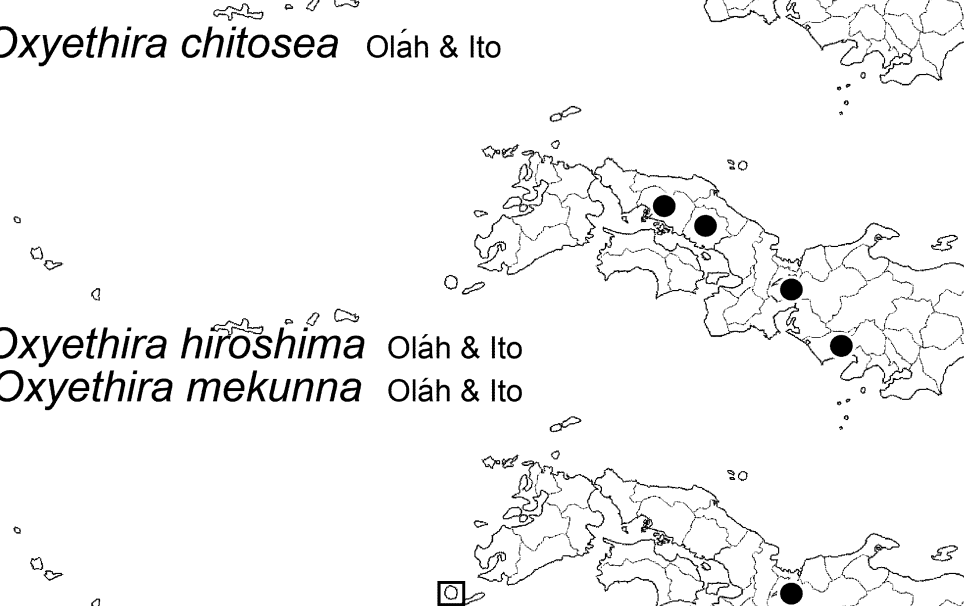

电的因

Oxyethira miea Olán \& Ito

Oxyethira okinawa Olán \& Ito
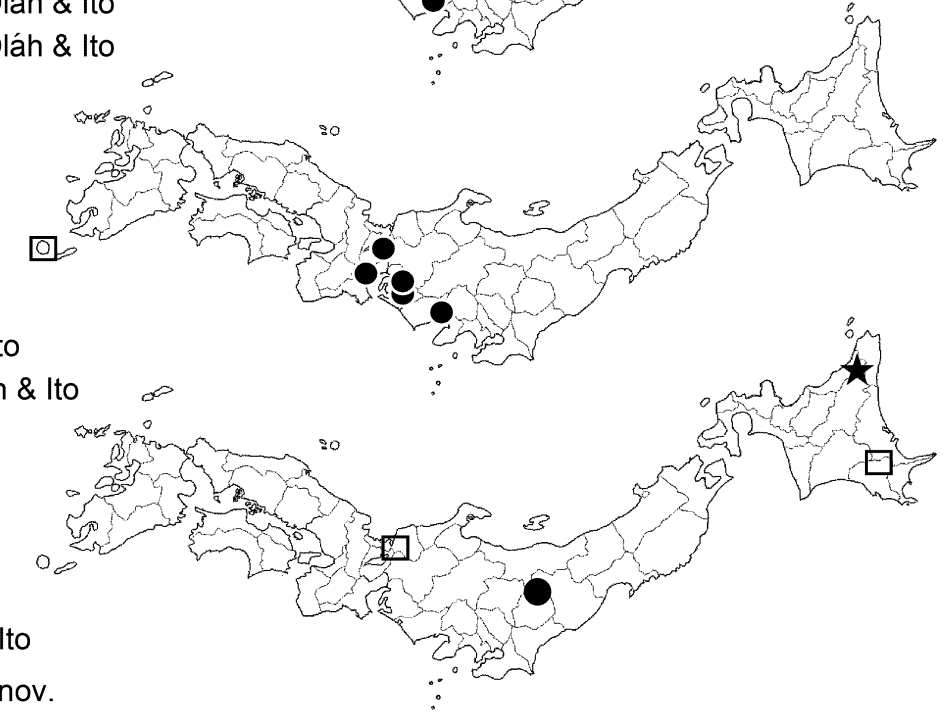

- Oxyethira ozea Oláh \& Ito

Oxyethira tsuruga sp. nov.

$\star$ Oxyethira shumari sp. nov.

Figure 12. Distributions of 10 named species of Oxyethira in Japan. 


\section{Oxyethira sp.}

These specimens appear to be an undescribed or unrecorded species collected in southern Ryukyu and will be dealt with when male material becomes available.

Material exmined. Ryukyu Islands. Ishigakijima: 1 female, Shiramizu, Nagura-gawa, small tributary, 25.x.2015, TI, S; 1 female, same loclity, 18.iii.2016, TI, S; 2 females, foot of Mt. Omotodake, 18-19.iii.2002, I. Oshima et al., L. Iriomotejima: 1 female, Nishi-funatsuki-gawa, Nishi-funatsuki-bahi, 20.iii.1996, F. Nishimoto, L; 1 female, same locality, 23.iii.216, TI, 1; 1 female, Airagawa, lower reach, 28-30.x.2012, TI, P.

\section{Species erroneously assigned to the genus Oxyethira}

\section{Hydroptila dampfi Ulmer, 1929}

Oxyethira ezoensis Kobayashi, 1977, 5-7, pl. 5, Japan (Hokkaido); Kelley, 1984, 442. Synonymized with Hydroptila itoi Kobayashi by Ito and Kawamula (1984).

Remarks. The senior author (T. Ito) examined the type series of Oxyethira ezoensis in the laboratory of Dr. Mineo Kobayashi, Kanagawa Prefectural Museum (Yokohama) in March, 1978 and recognized it as the females of Hydroptila itoi Kobayashi, 1977 (Ito \& Kawamula 1984, p. 315). $H$. ito $i$ was synonymized to $H$. dampfi Ulmer by Ito et al. (2011).

Acknowledgements - We are sincerely thankful to many Japanese biologists for the gift or loan of valuable specimens: Takaki Ogasawara, Towada-shi; the late Toshio Hattori, Shizuoka-shi; Ayuko Ohkawa, Tokyo University; Hiroyuki Nishimoto, Komaki-shi; Noriyoshi Shimura, Yokohama-shi; Koichi Nojima, Uesuko Co. Ltd.

\section{REFERENCES}

ITO, T. (2005): Hydroptilidae. In. KAWAI, T. \& TANIDA, K. (Eds.), Aquatic Insects of Japan: Manual with Keys and Illustrations. Tokai University Press, Kanagawa, p. 440-446 [in Japanese].
ITO, T. (2017): Caddisflies (Trichoptera) of Ikenokôchi Marsh, Tsuruga-shi, Fukui Prefecture, central Japan. Biology of Inland Waters, 31: 1-9 [in Japanese with English abstract].

ITO, T. \& KAWAMUlA, H. (1984): Morphology and ecology of the immature stages of Oxyethira acuta Kobayashi (Trichoptera, Hydroptilidae). Japanese Journal of Limnology, 45: 313-317. doi: $\underline{10.3739 / \text { rikusui.45.313 }}$

ITO, T., OHKAWA, A. \& HATTORI, T. (2011): The genus Hydroptila Dalman (Trichoptera, Hydroptilidae) in Japan. Zootaxa, 2801: 1-26.

KELLY, R.W. (1984): Phylogeny, morphology and classification of the micro-caddisfly genus $O x y$ ethira Eaton (Trichoptera: Hydroptilidae). Transactions of the American Entomological Society, 110: 435-463.

KELLY, R.W. (1985): Revision of the micro-caddisfly genus Oxyethira (Trichoptera: Hydroptilidae). Transactions of the American Entomological Society, 111: 223-253.

KoBAYASHI, M. (1977): The list and new species of the caddisflies from Hokkaido, Japan (Trichoptera, Insecta). Bulletin of the Kanagawa Prefectural Museum (Natural Science), 10: 1-14.

KuHARA, N. \& ITO, T. (2017): Caddisflies (Trichoptera) of the Yakushima, northern Ryûkyû, southwestern Japan. Biology of Inland Waters, 31: 11-20 [in Japanese with English abstract].

KUMANSKI, K. (1990): Studies on the fauna of Trichoptera (Insecta) of Korea. I. Superfamily Rhyacophiloidea. Historia naturalis bulgarica, 2: 36-59.

MARSHALL, J. E. (1979): A review of the genera of the Hydroptilidae (Trichoptera). Bulletin of the British Museum (Natural History), Entomology series, 39 (3): 135-239.

MARTYNOV, V. (1933): On an interesting collection of Trichoptera from Japan. Annotationes Zoologicae Japonnenses, 14: 139-156.

NozaKi, T., ITO, T. \& ToJo, K. (in press): Caddisflies collected with a Malaise trap at a springbrook of the Shimauchi-yusui in the Matsumoto Basin, central Japan: fauna and phenology. Proceedings of the 15th International Symposium on Trichoptera.

OHtaka, A., Ogasawara, T., Kimura, N., KobaYAShI, T., TANIDA, K., UENISHI, M., ABE, H., TOMIKAWA, K. \& KushitA, T. (2008): Benthic 
invertebrate fauna in the Byobu-san Lakes, Aomori Prefecture, northern Japan. Celastrina, 43: 49-78 [in Japanese].

OLÁH, J. \& ITO, T. (2013): Synopsis of the Oxyethira flavicornis species group with new Japanese Oxyethira species (Trichoptera, Hydroptilidae).
Opuscula Zoologica Budapest, 44 (1): 23-46.

Shimura, N., Yoshinari, G., Morimoto, S., TOKOro, T. \& KOMORI, C. (2014): Collection records of aquatic invertebrates from Amami Island, Kagoshima Prefecture. Hyôgo Freshwater Biology, 65: 35-60 [in Japanese]. 